\title{
Analysis of Post-Burial Soil Developments of Pre-AD 79 Roman Paleosols near Pompeii (Italy)
}

\author{
Sebastian Vogel ${ }^{1 *}$, Michael Märker ${ }^{2,3}$ \\ ${ }^{1}$ University of Tübingen c/o German Archaeological Institute, Berlin, Germany \\ ${ }^{2}$ Heidelberg Academy of Sciences and Humanities c/o University of Tübingen, Tübingen, \\ Germany \\ ${ }^{3}$ Department of Earth Sciences (DST), University of Florence, Florence, Italy \\ Email: seb vogel@gmx.de
}

Received 11 August 2014; revised 5 September 2014; accepted 16 September 2014

Copyright (C) 2014 by authors and Scientific Research Publishing Inc.

This work is licensed under the Creative Commons Attribution International License (CC BY). http://creativecommons.org/licenses/by/4.0/

(c) (i) Open Access

\section{Abstract}

The AD 79 eruption of Somma-Vesuvius completely buried the ancient landscape around Pompeii (Italy) to some extent conserving the pre-AD 79 Roman paleosols of the Sarno River plain. To estimate potential post-burial soil developments of these paleosols detailed soil liquid and solid phase analysis were carried out. Firstly, an in-situ soil hydrological monitoring was conducted within a pre-AD 79 paleosol in natural undisturbed stratification. The results show that soil water flow and nutrient transport from the overlying volcanic deposits into the pre-AD 79 paleosol take place. Secondly, to estimate their influence on the paleosol's mineral soil properties, the solid phase of four pre-AD 79 paleosols and associated modern unburied soils were analysed and compared. By combining the data from the soil liquid and solid phase analysis, potential post-burial changes in the paleosols were estimated. Finally, a rise of the mean groundwater table was determined since AD 79. This distinguishes the Sarno River plain into two different zones of post-burial soil developments: 1) lower altitudes where formerly terrestrial paleosols are now influenced by groundwater dynamics and 2) higher altitudes where the paleosols are still part of the vadose zone and rather influenced by infiltration water or interflow. Thus, the mechanism of potential post-burial soil development being active in the pre-AD 79 paleosols is not uniform for the entire Sarno River plain but strongly depends on the paleotopographic situation.

\section{Keywords}

Soil Liquid Phase, Soil Solid Phase, Post-Burial Soil Developments, Pre-AD 79 Roman Paleosol, Pompeii, Somma-Vesuvius

\footnotetext{
"Corresponding author.
} 


\section{Introduction}

Paleosols are geoarchives of a past soil formation since diverse mechanisms of burial can contribute to a preservation of original soil properties. Consequently, paleosols can yield important information on paleopedological and paleoenvironmental conditions before burial. However, a critical use of paleosol characteristics in interpreting paleoenvironments must be applied because pronounced diagenetic processes, i.e. post-burial soil developments, can take place, such as (Crowther et al., 1996 [1]; Retallack, 1998 [2], 2001 [3]; French, 2003 [4]).

1) Decomposition of soil organic matter (SOM)

Within well drained terrestrial soils SOM is decomposed after burial by aerobic microorganisms. That can be detected by a change in the Munsell soil colour towards brighter values (higher chroma). However, the general depth function of the SOM concentration of the paleosol stays mostly unaltered.

2) Leaching of nutrients from the overlying strata

In highly permeable substrate seepage water can lead to a dislocation of bases from the upper layers into the paleosol and hence to an alteration of the paleosol's nutrient status.

3) Soil compaction after burial

The superimposed load of the overlying deposits can cause soil compaction and a reduction of pore space.

Due to the probability of post-burial soil developments detailed field descriptions and laboratory analyses are necessary to understand both past and present pedogenetic processes that lead to the present-day appearance and properties of a paleosol (Scudder et al., 1996 [5]). Combined soil solid and liquid phase studies are a powerful tool to study post-burial soil developments. If the analysis of the soil solid phase provides good information about the factors and processes that influence a soil since the beginning of pedogenesis, soil liquid phase chemistry helps to understand active pedogenic processes. Gravitational water particularly represents the mobile fraction of the soil liquid phase that percolates through the soil profile and interacts and communicates with the entire stratigraphy. Consequently, measuring the chemical composition of the gravitational water most notably reflects the active redistribution and mobility of substances within the soil profile by vertical or lateral transport processes (Ugolini and Dahlgren, 1987 [6]; Wolt, 1994 [7]; Snakin et al., 2001 [8]). The analysis of the soil liquid phase within a buried paleosol enables the identification of those processes that are recently active and are likely to influence the paleosols solid phase properties after burial. Finally, by combining soil liquid and solid phase studies an estimate about post-burial soil developments can be made.

The explosive eruption of Somma-Vesuvius AD 79 almost completely buried the ancient landscape around Pompeii to some extent conserving the pre-AD 79 Roman paleosols. Foss, 1988 [9] and Foss et al., 2002 [10], investigated pre-AD 79 paleosols in the Pompeii area and stated that they show little disturbance or destruction. The paleosols were very similar to the modern soils suggesting a similar environment for soil development before and after AD 79. The paleosols developed in pumice and ash analog to the present-day soils. However, the paleosols had a higher $\mathrm{pH}$ value and a higher nutrient content (Foss, 1988 [9]). Thus, Foss, 1988 [9], and Foss et al., 2002 [10], presumed this to be the result of bases $\left(\mathrm{Ca}^{2+}, \mathrm{Mg}^{2+}\right)$ leaching from the overlying volcanic sediments and recharging the surface horizons of the paleosols.

Inoue et al., 2009 [11], investigated the pre-AD 472 paleosols at Somma Vesuviana around $15 \mathrm{~km}$ north of Pompeii. It developed from the AD 79 pyroclastic deposits and was buried during the AD 472 eruption of SommaVesuvius. These paleosols also showed higher $\mathrm{pH}$ values compared to the modern soils which they also attributed to leaching of bases from the overlying tephra deposits and accumulation in the paleosols.

As from today's state of research little is known about the development of volcanic paleosols after their burial (Zehetner et al., 2003 [12]; Agnelli et al., 2007 [13]) the objective of this study is to analyse both the soil liquid and solid phase of pre-AD 79 paleosols near Pompeii to get deeper insight into potential post-burial soil developments. Special attention is given to the evaluation of Foss' und Inoue's hypothesis of nutrient transport by soil water flow from the overlying volcanic deposits into the paleosols. Furthermore, present-day groundwater data and the pre-AD 79 topography (Vogel and Märker, 2010 [14]; Vogel et al., 2011 [15]) will be used to estimate the post-AD 79 groundwater trend with respect to the pre-AD 79 paleosol. This aims at confining the area of the Sarno River plain where the preAD 79 paleosol is no longer part of the vadose zone but recently influenced by groundwater dynamics.

\section{Research Area}

The soil liquid and solid phase was studied in the vicinity of Pompeii. It is located in the Sarno River plain in the 
southern part of the Campanian plain and southwest of Somma-Vesuvius volcanic complex (Figure 1). The stratigraphic sequence of the study area is particularly composed of volcaniclastic deposits from the periodic activity of Somma-Vesuvius as well as soil formations during phases of volcanic quiescence. Soils develop on ash, pumice or scoria lapilli fallout, pyroclastic surges and lava flows whereas pedogenesis especially depends on deposition modalities of the volcanic material, pedoclimatic conditions, topography, anthropogenic activity and time (Lulli, 2007 [16]).

The climate of the study area is Mediterranean with almost $70 \%$ of the annual precipitation falling between October and March and a pronounced dry summer season. On a long term average the mean annual precipitation is $865 \mathrm{~mm}$ whereas November is the wettest month with $129 \mathrm{~mm}$ and July is dryest with $16 \mathrm{~mm}$. The mean annual temperature is $17.4^{\circ} \mathrm{C}$. The hottest month is August with a mean temperature of $25.7^{\circ} \mathrm{C}$ whereas January is coolest with $9.6^{\circ} \mathrm{C}$ (Osservatorio Meteorologico, Università di Napoli Federico II, from 1870 to today).

The soil liquid phase was sampled within the archaeological excavation of Villa Regina (Boscoreale) around $1.3 \mathrm{~km}$ northwest of ancient Pompeii. Topographically, this Roman farm (villa rustica) is situated in a longitudinal depression between the western footslopes of the Pompeiian hill and the southern footslopes of Somma-

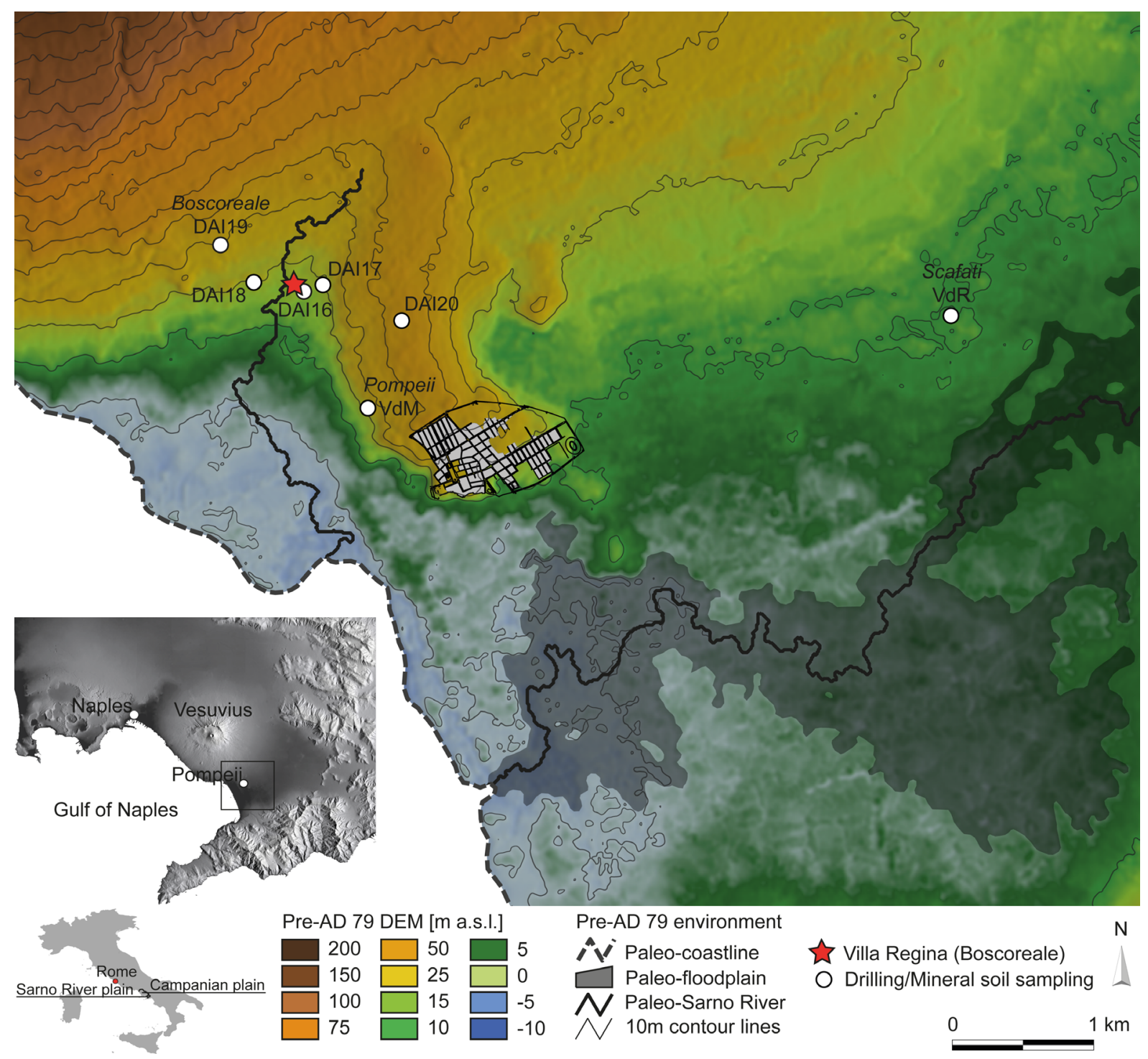

Figure 1. Paleotopographic location of the soil water monitoring (Villa Regina) northwest of ancient Pompeii and surrounding soil sampling sites. The stratigraphic section of DAI16 shows that at Villa Regina the pre-AD 79 paleosol is situated in a depth of around $8 \mathrm{~m}$ and overlain by recurring pyroclastic material, fluvial deposits and soil substrate. 
Vesuvius (Figure 1). There are two main reasons why Villa Regina was chosen for the soil liquid phase analysis:

1) The post-AD 79 deposits at the footslopes of Somma-Vesuvius have an above-average thickness of $8 \mathrm{~m}$ compared to other parts of the plain. Consequently, in case soil water flow into the paleosol can be detected at Boscoreale it is likely to be occurring in most areas of the Sarno River plain where the post-AD 79 deposits are usually thinner.

2) At the archaeological excavation of Villa Regina the pre-AD 79 paleosol was easily accessible to install the soil hydrological monitoring system in natural and undisturbed stratigraphy. Furthermore, it was protected from vandalism over the study period of 20 months.

The soil solid phase was sampled at three different sites incorporating different topographic situations as well as slightly different stratigraphic conditions (Figure 1):

1) Scafati (Via della Resistenza (VdR)): This site is located in the river plain approximately $3 \mathrm{~km}$ east of ancient Pompeii. The pre-AD 79 paleosol is situated in a depth of about $3.3 \mathrm{~m}$. It is covered by $2 \mathrm{~m}$ of pumice fallout and $0.9 \mathrm{~m}$ of pyroclastic density current (PDC) deposits from the explosive AD 79 eruption of SommaVesuvius followed by a medieval paleosol and the modern soil.

2) Pompeii (Villa dei Misteri (VdM)): It is situated at the southwestern slope of the Pompeiian hill near the archaeological site of Villa dei Misteri and about $350 \mathrm{~m}$ northwest of the city walls of ancient Pompeii. The preAD 79 paleosurface appears in a depth of $5.7 \mathrm{~m}$. The thicknesses of overlying AD 79 pumice fallout and PDC deposits are about $2.3 \mathrm{~m}$ and $1.7 \mathrm{~m}$, respectively. This is followed by about $1.7 \mathrm{~m}$ of a medieval paleosol and the modern soil (Rispoli et al., 2008 [17]).

3) Boscoreale (Villa Regina (VR)): Five mechanical core drillings were carried out near the archaeological excavation of Villa Regina (VR) along a NW-SE transect crossing the longitudinal depression between the Pompeiian hill and Somma-Vesuvius. The drillings DAI18 and DAI19 are situated in the northwest at the footslope of Somma-Vesuvius whereas DAI17 is located at the footslope of the Pompeiian hill. DAI16 is situated at the bottom of the depression at the exact location of the soil liquid phase analysis whereas DAI20 is located on top of the Pompeiian hill in the southeast (Vogel and Märker, 2012 [18]). At DAI16 the pre-AD 79 paleosol is covered by approximately $2.5 \mathrm{~m}$ of AD 79 pumice fallout and PDC deposits. This is overlain by volcanoclastics from later eruptions and intercalated fluvial deposits and pedogenised soil material representing phases of volcanic quiescence. This results in a total thickness of post-AD 79 deposits of around $8 \mathrm{~m}$ lying on top of the preAD 79 paleosurface.

According to groundwater data of the "Autorità di Bacino del Sarno" the pre-AD 79 Roman layer of the three study sites is not influenced by groundwater. Thus, the pre-AD 79 paleosols are part of the vadose zone and soil water within the profile derives vertically from infiltration water or laterally from interflow.

\section{Material and Methods}

To assess the post-burial soil developments of the pre-AD 79 Roman paleosols near Pompeii, we conducted soil liquid and solid phase analysis combined with an estimation of the post-AD 79 groundwater trend. Consequently, the following sections will be subdivided accordingly.

\subsection{Groundwater Table}

Between the eruption of Somma-Vesuvius in AD 79 and today a relative rise of the groundwater table can be determined for the Sarno River plain. Consequently, in many parts of the inner plain, although terrestrial before $\mathrm{AD} 79$, the pre-AD 79 paleosol has come under the influence of groundwater. To calculate this approximate rise of the groundwater table since AD 79 and to confine the zone where the primal terrestrial pre-AD 79 paleosol is recently influenced by groundwater dynamics, present-day groundwater data were combined with the pre-AD 79 topography (Vogel and Märker, 2010 [14]; Vogel et al., 2011 [15]).

At first, the depth of the present-day mean annual groundwater table was modelled from more than 5600 groundwater observation points (by courtesy of the Autorità di Bacino del Sarno). Thereafter, this groundwater table was subtracted from the pre-AD 79 digital elevation model (DEM) of the Sarno River plain to determine the area where the groundwater table recently lies above the pre-AD 79 soil surface. Vogel et al., 2011 [15], modelled the pre-AD 79 floodplain or wetlands related to the paleo-Sarno River which are characterised by fluvial/palustrine deposits before AD 79. In general, wetlands show a water table that stands at or near the ter- 
rain surface for a sufficient period of the year to allow the development of palustrine deposits (Brinson, 1993 [19]). Consequently, the reconstructed paleofloodplain can be considered as the area where, before AD 79, the mean groundwater table was at or near the pre-AD 79 paleosurface (Figure 1).

From these two groundwater levels (at the pre-AD 79 surface, today and before AD 79) the mean "altitude above channel network" index (AACN; SAGA terrain analysis module; $0.06 \%$ channel network density) was deduced from the pre-AD 79 DEM. The AACN calculates the vertical distance to the pre-AD 79 Sarno River and thus directly reflects the groundwater table. Finally, by subtracting the arithmetic means of the two indices the approximate rise of the groundwater table since AD 79 was determined.

\subsection{Soil Liquid Phase}

At the archeological excavation of Villa Regina (Boscoreale) a soil hydrological monitoring system was installed within the pre-AD 79 paleosol in natural stratification. It aims at determining if the pre-AD 79 paleosol is subject to soil water flow from the overlying volcanic deposits either vertically by percolation or laterally by interflow. The soil moisture and the soil liquid phase were determined in-situ by means of frequency domain reflectometer (FDR) and tension lysimeters (suction cups), respectively. Tension lysimeters were used since this methodology predominantly samples the mobile fraction of soil water that moves through inter-aggregate pores or preferential flow channels and thus reflects the chemical transport within the stratigraphy (Wolt, 1994 [7]). Due to the depth of the pre-AD 79 paleosol of about $8 \mathrm{~m}$ a vertical installation from the present-day surface was not feasible. Consequently, the installation was implemented laterally inside the natural undisturbed stratification of the side walls of the archaeological excavation of Villa Regina (Figure 2).

Altogether four sampling systems were installed, two within the lower section of the AD 79 pumice fallout layer and two within the pre-AD 79 paleosol underneath. The composition of the soil liquid phase may not directly refer to specific chemical processes active in the pre-AD 79 paleosol. Nevertheless, the net effect of recent

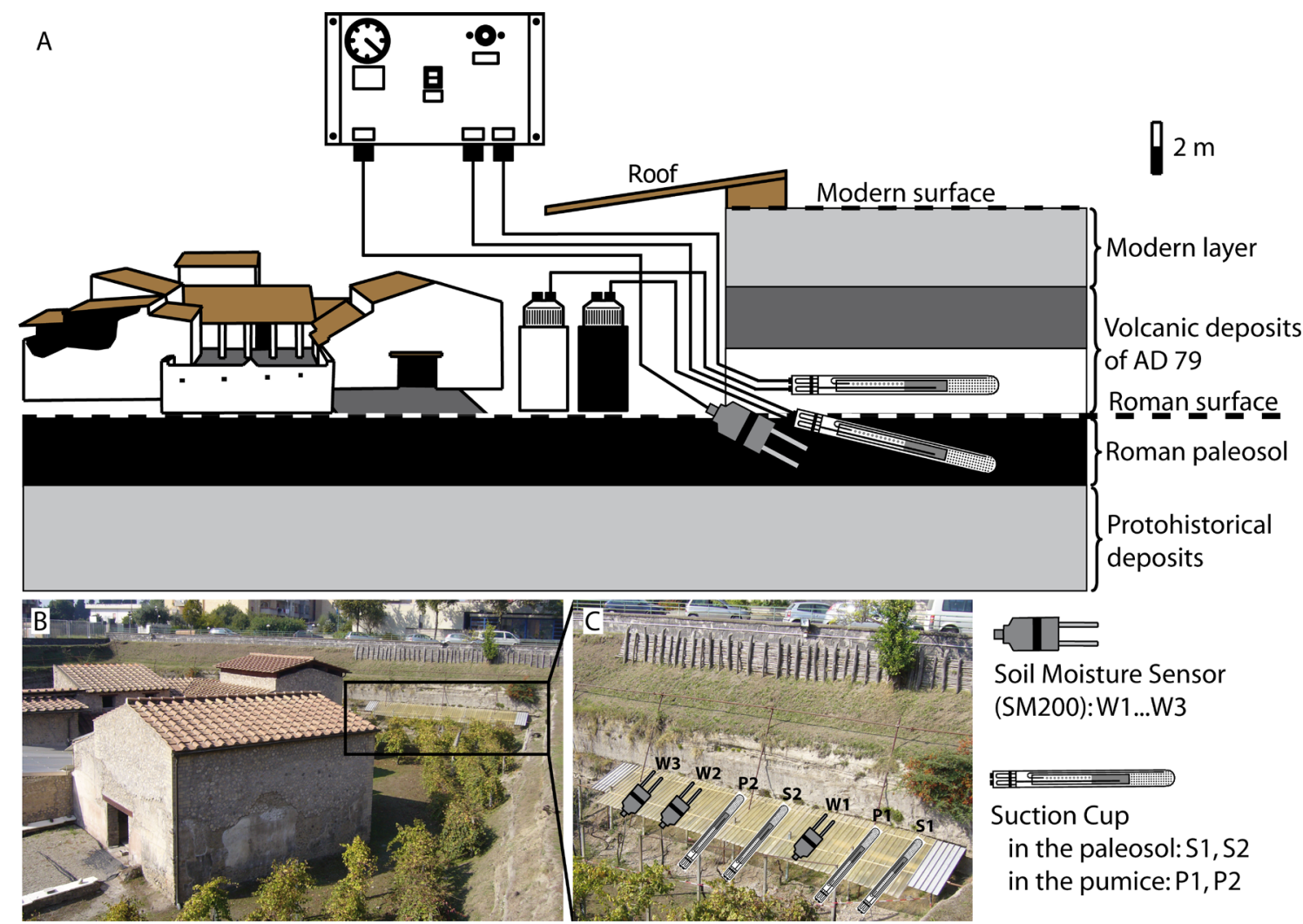

Figure 2. Schematic view of the experimental setup using suction cups and soil moisture sensors (SM200) (A). The study site is situated at the northern edge of the archaeological excavation of Villa Regina (Boscoreale) (B). A roof was build to protect the installation from precipitation water entering the excavation (C). 
transport of nutrients into the paleosol is manifested in the concentration of substances in the soil water extract (Wolt, 1994 [7]). Consequently, the main objective of the given sampling design is to determine if a soil water flow to the pre-AD 79 paleosol occurs. Moreover, we provide data of the general trends in the soil liquid phase chemistry, i.e. the occurrence of certain ions in the lysimeter solution at the point of sampling (Grossmann and Moss, 1994 [20]; de Vries and Leeters, 1994 [21]; Wolt, 1994 [7]; Manderscheid and Matzner, 1995 [22]).

Due to the remarkable depth of burial and the absence of interactions with present-day plant roots the composition of the soil liquid phase within the pre-AD 79 paleosol will be less heterogeneous compared to the rooting zone of the modern soil. This may also be favoured by the relative chemical homogeneity of the AD 79 pumice fallout layer overlying the pre-AD 79 paleosol. Consequently, four sampling systems are expected to yield qualitative data on the soil liquid phase chemistry of the sampling area.

In the paleosol the suction cups were installed in slurry of the paleosol material to ensure an optimal contact between the instrument and the surrounding soil and a minimum of disturbance. Because of the coarseness of the AD 79 pumice lapilli layer above, the suction cups could not be installed in its own material. Hence, silica slurry of fine sand was used having a low adsorption capacity to minimise the influence of the slurry material on the soil liquid phase.

To extract the soil liquid phase a transient tension (vacuum) of 550 mbar ( $\mathrm{pF}$ 2.7) was established biweekly to the suction cups by evacuation with an external pump. Due to a slight decrease of tension during the two weeks between evacuations an applied tension of 550 mbar enables the sampling of the soil liquid phase near field capacity. Even though the gradient generated by the suction cups will not exclusively act on macropores but to some extent also on smaller pores (Grossmann and Udluft, 1991 [23]) the applied tension predominantly samples the mobile soil water fraction. The approximate pore diameter that is drained at a certain soil water potential can be calculated by means of the law of capillary rise or the Young-Laplace equation:

$$
r=\frac{2 \gamma \cos \alpha}{h p_{w} g}
$$

where $r$ is the radius of the capillary tube, $\gamma$ the surface tension of water, $\alpha$ the contact angle, $h$ the water potential, $p_{w}$ the density of water and $g$ the gravitational acceleration (Scheffer and Schachtschabel, 2010 [24]). Hence, applying a tension of 550 mbar and assuming complete wettability ( $\alpha=0$ ) of the substrate the suction cups extract water from soil pores of a minimum diameter of $5.4 \mu \mathrm{m}$ which corresponds to intermediate sized pores.

Through the introduction of oxygen into the soil during installation of the suction cups the biological activity of the paleosol may be stimulated causing a mobilization of nutrients. This can influence the composition of the soil liquid phase directly after installation (Grossmann, 1988 [25]). For this reason, the obtained lysimeter solution was rejected for the first months after installation. From the installation to the first soil water sampling the system had about three months to re-equilibrate.

The suction cups were installed $1.5 \mathrm{~m}$ inside the stratigraphy to prevent them from being influenced by water entering the soil profile from the open excavation side of Villa Regina. Furthermore, the installation was carried out on the upslope part of the excavation assuring that rain water directly entering the excavation is diverging. Additionally, the entire installation was covered by a roof over its whole length (Figure 2).

Suction cups were used that collect the solution in their interior. That has the advantage that the extracted water stays cool and protected from sunlight until the sampling takes place, minimising chemical transformations within the lysimeter solution. Due to its specific adsorption characteristics the filter material of the suction cup may have an influence on the composition of the sample. Consequently, the investigation of a certain analyte requires a particular filter material. As this study focusses on dissolved inorganic substances polyamide filters were used (Litaor, 1988 [26]; Grossmann, 1988 [25]; DVWK, 1990 [27]; Haberhauer, 1997 [28]; Spangenberg et al., 1997 [29]; Tischner et al., 1998 [30]).

The composition of the soil liquid phase was monitored over a period of 20 months to cover the variability throughout the year. The autumn and winter period was studied twice. This period is believed to be most relevant because the precipitation maximum and relatively low evapotranspiration between October and March is most likely to cause soil water flow down to the pre-AD 79 paleosol. The soil liquid phase in the suction cups was controlled biweekly, sampled and analysed for: 1) $\mathrm{pH}$ value, 2) major cations $\left(\mathrm{Ca}^{2+}, \mathrm{Mg}^{2+}, \mathrm{K}^{+}, \mathrm{Na}^{+}\right)$and anions $\left(\mathrm{SO}_{4}^{2-}, \mathrm{HPO}_{4}^{2-}, \mathrm{NO}_{3}^{-}, \mathrm{Cl}^{-}\right)$because of their importance for soil fertility and nutrient conditions and 3 ) $\mathrm{Al}^{3+}$ because of its relevance in terms of the acidity status and plant physiology (Al-toxicity) (Hendershot and 
Courchesne, 1991 [31]; Wolt, 1994 [7]; Fillion et al., 1999 [32]; Derome, 2002 [33]; Roman et al., 2002 [34]; Strahm et al., 2005 [35]).

Since the composition and amount of the soil liquid phase sampled by the tension lysimeters varies with soil water content, additionally, three soil moisture sensors (SM200) where installed in the paleosol measuring the volumetric water content $(\theta)$ every six hours. The SM200 soil moisture sensor is a frequency domain reflectometer (FDR) measuring $\theta$ indirectly by determining the permittivity of the soil (Delta-T Devices Ltd., 2006 [36]).

The soil liquid phase of the vadose zone strongly depends on water deriving from precipitation. To get a rough estimate of how the precipitation regime interacts with the soil moisture of the pre-AD 79 paleosol and its soil water chemistry throughout the year, meteorological data were collected (Campania Region). It may not be possible to relate a single precipitation event to the soil water sampled in the paleosol at a depth of $8 \mathrm{~m}$. Nevertheless, especially the time between the first precipitations in autumn and the first response in the paleosol's soil moisture as well as the first soil water sampling will be of particular interest. Moreover, the first soil water flow after the dry summer season is expected to have a strong influence on the composition of the soil liquid phase in terms of higher element concentrations that are leaching into the pre-AD 79 paleosol (Arthur and Fahey, 1993 [37]).

\subsection{Soil Solid Phase}

At Scafati, Pompeii and Boscoreale modern soils and associated pre-AD 79 paleosols were identified in four stratigraphies (DAI16, DAI18, VdM, VdR). They were described in the field and the soil solid phase was sampled for the subsequent soil physical and chemical laboratory analyses.

Following generally Retallack, 1998 [2], 2001 [3] and French, 2003 [4], as well as in particular Foss, 1988 [9], Foss et al., 2002 [10] and Inoue et al., 2009 [11], we hypothesise that post-burial soil changes in the pre-AD 79 paleosols may above all be associated with nutrient transport from the overlying strata and decomposition of soil organic matter (SOM). Hence, to determine post-burial soil developments, the soil solid phase of both the preAD 79 paleosols and the associated modern soils were analysed and compared. Thereby, the modern soils were taken as a reference for an unburied volcanic soil.

To assess the effects of soil water flow and associated nutrient transport on the mineral soil properties the following analyses were carried out: 1) soil pH measured in $0.01 \mathrm{M} \mathrm{CaCl}_{2}$ (DIN ISO 10390 [38]); 2) effective cation exchange capacity $\left(\mathrm{CEC}_{\text {eff }}\right)$ and the amount of exchangeable cations ( $\mathrm{K}, \mathrm{Na}, \mathrm{Ca}, \mathrm{Mg}, \mathrm{Mn}, \mathrm{Al}$ and $\mathrm{Fe}$ ) by sequential extraction with unbuffered ammonium chloride; and 3) total inorganic carbon (TIC) by elementary analysis using the dry combustion reference method (DIN EN 13137 [39]).

To study the post-burial decomposition of soil organic matter in the paleosols total organic carbon (TOC) was determined by elementary analysis using the dry combustion reference method (DIN EN 13137 [39]) as well as total nitrogen using the modified method of Kjeldahl (DIN ISO 11261 [40]).

As mentioned earlier Foss, 1988 [9], stated that the environment for soil development before and after AD 79 was similar resulting in a relative similarity between the paleosols and the modern soils around Pompeii. Hence, for this comparison we presuppose similar climatic conditions before AD 79 and today. This is indicated by Sadori and Narcisi, 2001 [41], from lacustrine sediments in Sicily as well as from Buccheri et al., 2002 [42], from sea core data of the Salerno Gulf (southern Tyrrhenian Sea). However, similar vegetational conditions at the investigated sites have to be hypothesized as they are more difficult to determine. Isotope analysis of $\delta 13 \mathrm{C}$ and $\delta 15 \mathrm{~N}$ of the pre-AD 79 paleosols and the modern soils revealed a predominance of $\mathrm{C}_{3}$ vegetation before $\mathrm{AD} 79$ and today (Oelmann and Ruppenthal, 2012, written communication). Moreover, the comparison between the preAD 79 paleosols and the modern soils was only carried out at the same topographic location of each sampling point. This eliminates the influence of the relief as a soil forming factor in explaining soil variations.

The particular chemical composition of the modern soils and the pre-AD 79 paleosols may differ due to a slightly different geology of the parent volcanic material as well as due to anthropogenic input in terms of fertilizers or waste materials. This may falsify the comparison of the two soils. To characterise the chemical composition of the soils, total amounts of $\mathrm{Na}, \mathrm{Ca}, \mathrm{K}, \mathrm{Mg}, \mathrm{Mn}, \mathrm{Al}$ and $\mathrm{Fe}$ were determined by element analysis using aqua regia (nitrochloric acid) and AAS /ICP-AES. To eliminate the effect of a different geology of the soil substrate and anthropogenic input ratios were introduced correcting a particular measured element concentration by its total concentration (see Equations (2) and (3)). 
The CEC ratio allows for a comparison of the nutrient status of the paleosols and the modern soils even if both soils exhibit different total element concentrations. A consistently higher CEC ratio in the paleosols may for instance indicate nutrient input via leaching. As CEC is the sum of exchangeable cations the CEC ratio was calculated by dividing the cation exchange capacity by the sum of the total concentrations of $\mathrm{K}, \mathrm{Na}, \mathrm{Ca}$ and $\mathrm{Mg}$ (Equation (2)).

$$
\text { CEC ratio }=\frac{\mathrm{CEC}}{\left(\mathrm{K}_{\mathrm{tot}}+\mathrm{Natot}_{\mathrm{tatot}}+\mathrm{Mg}_{\mathrm{tot}}\right)}
$$

The nutrient ratio is used for the comparison of a particular nutrient cation, hence dividing the amount of an exchangeable cation $\left(\mathrm{K}_{\text {exch }}, \mathrm{Na}_{\text {exch }}, \mathrm{Ca}_{\text {exch }}, \mathrm{Mg}_{\text {exch }}\right)$ by the total amount of the respective element $\left(\mathrm{K}_{\text {tot }}, \mathrm{Na}_{\text {tot }}, \mathrm{Ca}_{\text {tot }}\right.$, $\mathrm{Mg}_{\text {tot }}$ ) (Equation (3)). Thus, the nutrient ratio helps to identify which nutrients are predominantly leaching from the volcanic deposits into the paleosols.

$$
\text { Nutrient ratio }=\frac{\text { Ionexch }_{\text {ent }}}{\text { Element }}
$$

By means of division by the total element concentrations, the CEC ratio and the nutrient ratios also eliminate methodical defects of the CEC method with respect to $\mathrm{CaCO}_{3}$ contents $>10 \mathrm{~g} \cdot \mathrm{kg}^{-1}$ which may cause dissolution of $\mathrm{CaCO}_{3}$ and increased values of CEC and exchangeable $\mathrm{Ca}^{2+}$ (Dohrmann and Kaufhold, 2009 [43]).

For the comparison between the modern soils and the pre-AD 79 Roman paleosols only topsoils were considered as in general they are characterised by high SOM and nutrient turnover rates as well as by major soil chemical reactions due to plant roots and microorganisms. Finally, considering the results of both the soil liquid and soil solid phase analysis major differences between the unburied modern soils and the buried paleosols are utilised to gain valuable insights into potential post-burial soil developments of the pre-AD 79 paleosols.

\section{Results}

\subsection{Groundwater Table}

The combination of the present-day groundwater table with the pre-AD 79 topography reveals that a large area of the inner Sarno River plain is affected by a groundwater table lying at or above the pre-AD 79 paleosurface (Figure 3). Altogether this comprises the area near the river network which amounts to around $75 \mathrm{~km}^{2}$ or $37 \%$ of the entire Sarno River plain. However, this includes an area of about $25 \mathrm{~km}^{2}$ or $32 \%$ where the pre-AD 79 layer was originally (before burial) characterised as a terrestrial paleosol. Consequently, there must have been a considerable rise of the groundwater table from AD 79 to the present day. This post-AD 79 groundwater rise was determined to approximately $1.8 \mathrm{~m}$.

\subsection{Soil Liquid Phase}

\subsubsection{Soil Water Flow}

Figure 4 shows the soil moisture $(\theta)$ of the pre-AD 79 Roman paleosol at Villa Regina and the precipitation regime for the period 2008/09. At the beginning of the study period in October 2008 the pre-AD 79 paleosol was still dry from the preceding summer season. This is supported by a constant and low initial $\theta$ of around $22 \%$. First single rainfall events started in September 2008 whereas the main rainy season with more regular and intense precipitation began in early November. However, it took about one month, until the beginning of December, for a first response of $\theta$ in the pre-AD 79 paleosol. Thus, the soil water needed about one month to percolate from the present-day surface to the pre-AD 79 paleosol in a depth of $8 \mathrm{~m}$.

The phase of rewetting of the pre-AD 79 paleosol after the dry summer season lasted from early December 2008 until February 2009 when $\theta$ continuously increased to its maximum of $25.8 \%$. The main rainy season terminated in mid-February with more sporadic rainfall events until the end of April. From mid March and again with a delayed response of about one month $\theta$ started to decrease, at first rather slightly and more explicitly from the end of April. Then $\theta$ decreased to its minimum of $13.6 \%$ in the end of September 2009. Finally, the soil moisture data reveal that the pre-AD 79 paleosol at Villa Regina was at no time of the year water saturated.

The first soil liquid phase was extracted by the suction cups at the end of December, another month after the first response of $\theta$. By the time of the first soil water sampling $\theta$ was $24.3 \%$. Henceforward, soil liquid phase could 


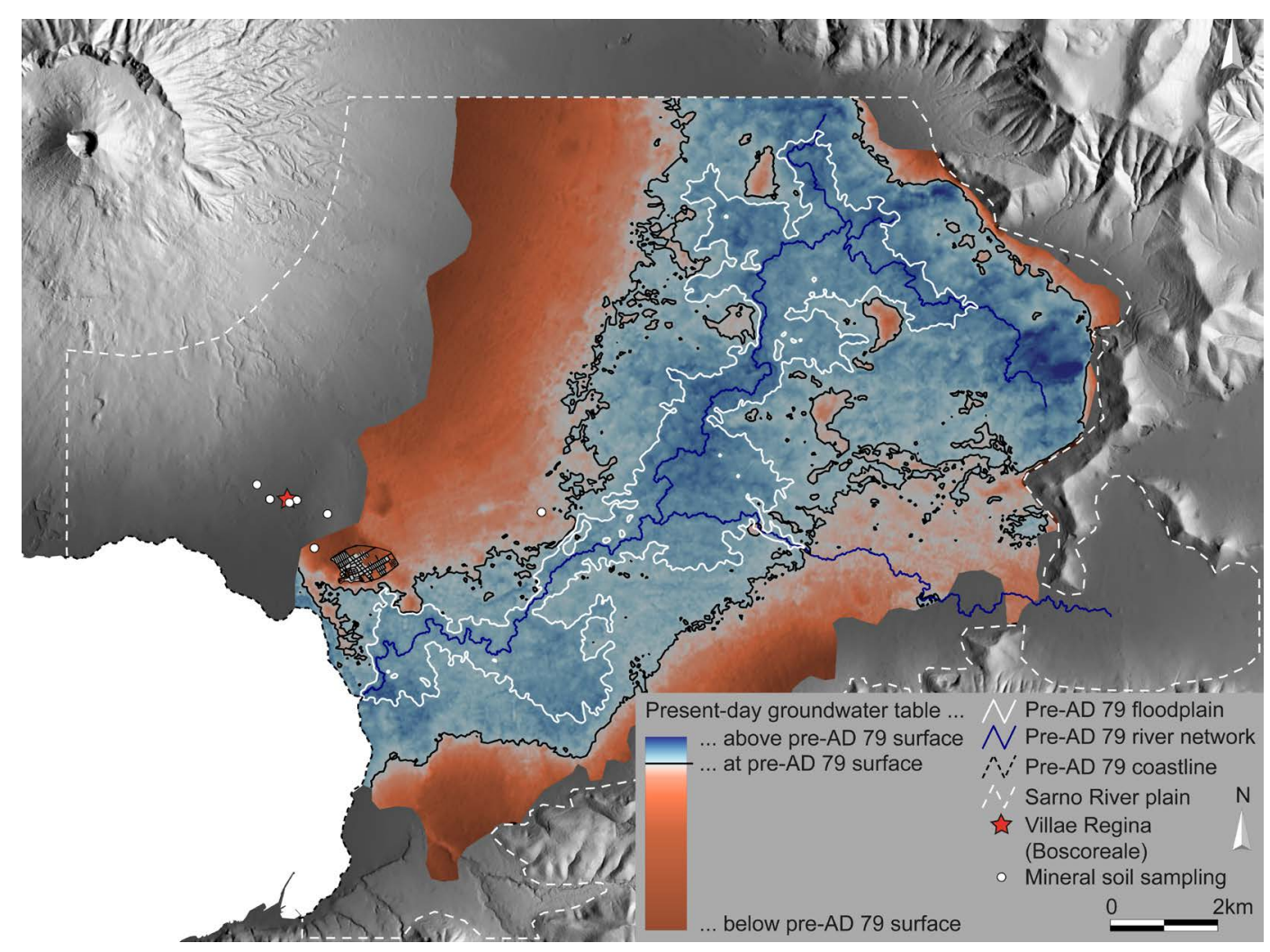

Figure 3. Model of the present-day mean groundwater table with respect to the pre-AD 79 paleosurface. The black line confines the area where the groundwater table is at or above the pre-AD 79 paleosurface (blue colours). Accordingly, the white line of the pre-AD 79 floodplain approximately describes the area where before $\mathrm{AD} 79$ the mean groundwater table was at or above the pre-AD 79 paleosurface.

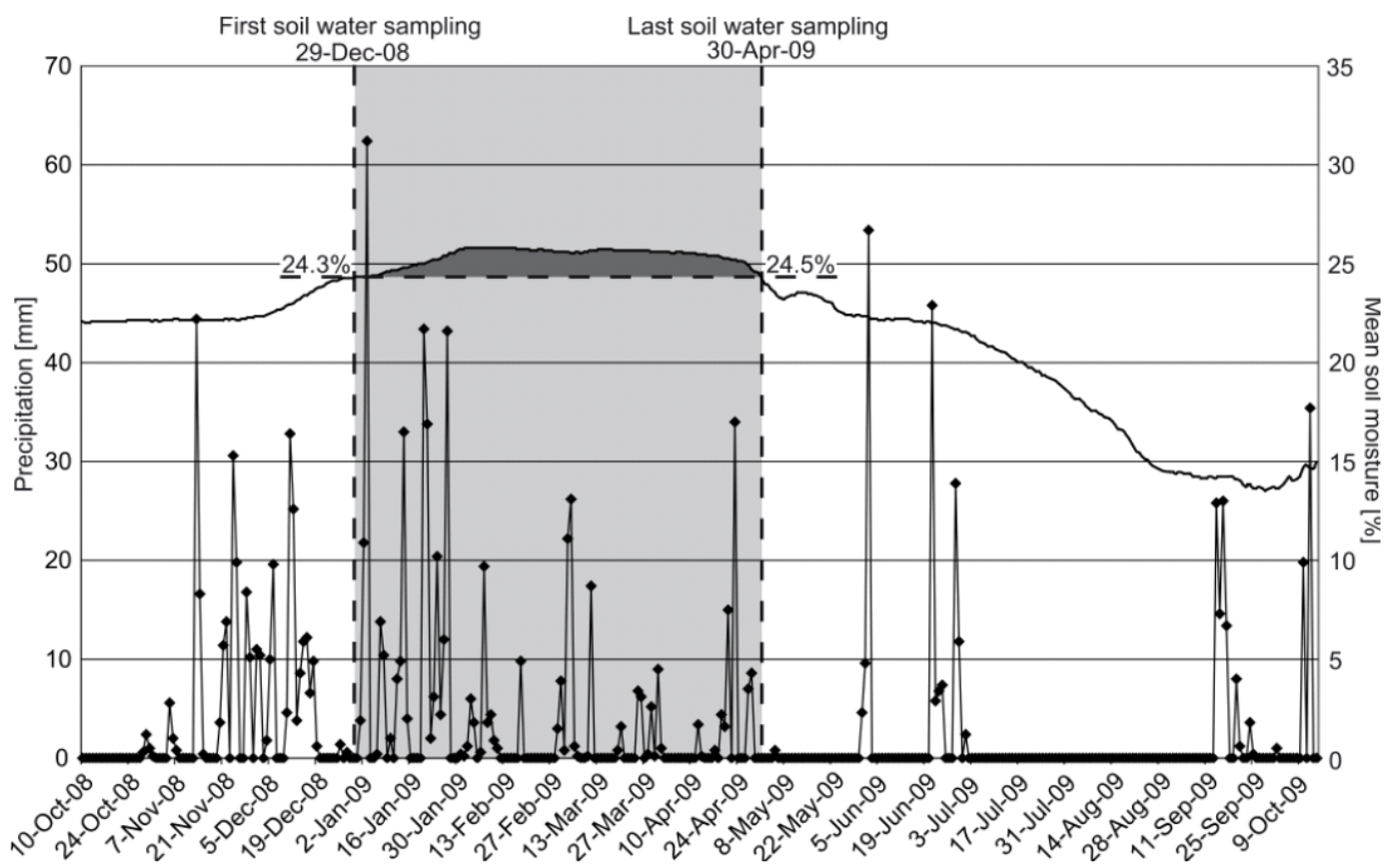

Figure 4. Soil moisture $(\theta)$ of the pre-AD 79 paleosol at Villa Regina (Boscoreale) and precipitation chart of Napoli-Osservatorio Meteo D.G.V. for the study period 2008/09. Highlighted is the period when mobile soil water could be extracted from the paleosol (light gray) when $\theta$ exceeded about $24.5 \%$ (dark gray). 
be sampled biweekly for the next four months until the end of April 2009. By the end of the sample period $\theta$ had decreased to $24.5 \%$.

In contrast to the pre-AD 79 paleosol no soil water could be extracted from the AD 79 pumice lapilli fallout directly above.

During the winter season of 2009/10 the first lysimeter sample was taken at the beginning of February 2010 about one month later than 2009. This coincides with the paleosol having a much lower initial soil moisture $(\theta)$ in the summer of 2009 (13.6\%) in comparison to 2008 (22\%) (Figure 4). Furthermore, in the first half of the rainy season, from October to January 2008/09, there were a total of $735 \mathrm{~mm}$ of precipitation in comparison to only $492 \mathrm{~mm}$ in 2009/10. Consequently, in 2009/10 the process of rewetting of the soil substrate took much longer until percolation took place and $\theta$ of the pre-AD 79 paleosol was sufficiently high for soil water to be sampled by the suction cups. Consequently, in 2009/10 the period of soil water sampling was shorter, lasting only 100 days in comparison to 120 days in 2008/09.

\subsubsection{Soil Water Chemistry}

The soil water chemistry of the 2008/09 and 2009/10 seasons is summarised in Tables 1 and 2. The pH value of the soil liquid phase represents the active acidity of the pre-AD 79 paleosol (Mengel and Kirkby, 2001 [44]). With a mean $\mathrm{pH}$ value of 7.5 the soil water extract is slightly alkaline, varying only marginally throughout the year. The mean cation concentrations are: $42.9 \mathrm{mg} / \mathrm{l}$ for $\mathrm{Ca}^{2+}, 35.6 \mathrm{mg} / \mathrm{l}$ for $\mathrm{K}^{+}, 23.3 \mathrm{mg} / \mathrm{l} \mathrm{for} \mathrm{Na}^{+}$and $5.7 \mathrm{mg} / \mathrm{l}$ for $\mathrm{Mg}^{2+}$. The mean anion concentrations are: $60.5 \mathrm{mg} / \mathrm{l}$ for $\mathrm{Cl}^{-}, 23.4 \mathrm{mg} / \mathrm{l}$ for $\mathrm{NO}_{3}^{-}$and $22.7 \mathrm{mg} / \mathrm{l}$ for $\mathrm{SO}_{4}^{2-}$. The mean calculated electrical conductivity ( $\mathrm{EC}_{\text {calc }}$ ) at $25^{\circ} \mathrm{C}$ is $441 \mu \mathrm{S} / \mathrm{cm}$. Only the first two soil water extracts at the beginning of the sample period contained very small amounts of aluminium whereas later on no $\mathrm{Al}^{3+}$ could

Table 1. Chemical properties of the soil water extract of the pre-AD 79 paleosols and the soil moisture $(\theta)$ at the date of sampling (sample period 2008/09). Soil water chemistry corrected for soil moisture is put in parentheses (ND, not detectable).

\begin{tabular}{|c|c|c|c|c|c|c|c|c|c|c|c|}
\hline Date of sampling & $\begin{array}{l}\text { 29-Dec } \\
2008\end{array}$ & $\begin{array}{c}\text { 14-Jan } \\
2009\end{array}$ & $\begin{array}{c}\text { 26-Jan } \\
2009\end{array}$ & $\begin{array}{c}\text { 9-Feb } \\
2009\end{array}$ & $\begin{array}{c}\text { 24-Feb } \\
2009\end{array}$ & $\begin{array}{c}\text { 9-Mar } \\
2009\end{array}$ & $\begin{array}{c}\text { 23-Mar } \\
2009\end{array}$ & $\begin{array}{l}\text { 6-Apr } \\
2009\end{array}$ & $\begin{array}{c}\text { 15-Apr } \\
2009\end{array}$ & $\begin{array}{c}\text { 30-Apr } \\
2009\end{array}$ & $\begin{array}{c}\text { Arithmetic } \\
\text { mean }\end{array}$ \\
\hline$\theta[\%]$ & 24.3 & 24.8 & 25.4 & 25.8 & 25.4 & 25.6 & 25.7 & 25.6 & 25.4 & 24.5 & 25.3 \\
\hline $\mathrm{pH}$ & 7.7 & 7.6 & 7.5 & 7.8 & 7.6 & 7.6 & 7.2 & 7.3 & 7.7 & 7.4 & 7.5 \\
\hline $\begin{array}{c}\mathrm{EC}_{\text {calc }}\left[\mu \mathrm{S} \mathrm{cm}^{-1}\right] \text { at } \\
25^{\circ} \mathrm{C}\left(\mathrm{EC}_{\text {calc }} / \theta\right)\end{array}$ & $\begin{array}{l}526.2 \\
(21.7)\end{array}$ & $\begin{array}{l}433.0 \\
(17.5)\end{array}$ & $\begin{array}{l}388.1 \\
(15.3)\end{array}$ & $\begin{array}{l}405.6 \\
(15.7)\end{array}$ & $\begin{array}{l}398.2 \\
(15.7)\end{array}$ & $\begin{array}{l}401.9 \\
(15.7)\end{array}$ & $\begin{array}{l}463.7 \\
(18.0)\end{array}$ & $\begin{array}{l}464.4 \\
(18.1)\end{array}$ & $\begin{array}{l}465.0 \\
(18.3)\end{array}$ & $\begin{array}{l}459.7 \\
(18.8)\end{array}$ & $\begin{array}{l}440.6 \\
(17.5)\end{array}$ \\
\hline \multicolumn{12}{|l|}{ Cations [mg l' $\left.{ }^{-1}\right]$} \\
\hline $\begin{array}{c}\mathrm{Ca}^{2+} \\
\left(\mathrm{Ca}^{2+} / \theta\right)\end{array}$ & $\begin{array}{c}41.1 \\
(1.69)\end{array}$ & $\begin{array}{c}40.4 \\
(1.63)\end{array}$ & $\begin{array}{c}38.2 \\
(1.50)\end{array}$ & $\begin{array}{c}38.3 \\
(1.48)\end{array}$ & $\begin{array}{c}38.1 \\
(1.50)\end{array}$ & $\begin{array}{c}39.3 \\
(1.54)\end{array}$ & $\begin{array}{c}48.0 \\
(1.87)\end{array}$ & $\begin{array}{c}48.0 \\
(1.88)\end{array}$ & $\begin{array}{c}48.6 \\
(1.91)\end{array}$ & $\begin{array}{c}48.7 \\
(1.99)\end{array}$ & $\begin{array}{c}42.9 \\
(1.70)\end{array}$ \\
\hline $\begin{array}{c}\mathrm{K}^{+} \\
\left(\mathrm{K}^{+} / \theta\right)\end{array}$ & $\begin{array}{c}45.6 \\
(1.88)\end{array}$ & $\begin{array}{c}39.3 \\
(1.58)\end{array}$ & $\begin{array}{c}37.1 \\
(1.46)\end{array}$ & $\begin{array}{c}33.8 \\
(1.31)\end{array}$ & $\begin{array}{c}32.9 \\
(1.30)\end{array}$ & $\begin{array}{c}32.8 \\
(1.28)\end{array}$ & $\begin{array}{c}33.7 \\
(1.31)\end{array}$ & $\begin{array}{c}33.7 \\
(1.32)\end{array}$ & $\begin{array}{c}33.6 \\
(1.32)\end{array}$ & $\begin{array}{c}33.8 \\
(1.38)\end{array}$ & $\begin{array}{c}35.6 \\
(1.41)\end{array}$ \\
\hline $\begin{array}{c}\mathrm{Na}^{+} \\
\left(\mathrm{Na}^{+} / \theta\right)\end{array}$ & $\begin{array}{c}24.5 \\
(1.01)\end{array}$ & $\begin{array}{c}25.1 \\
(1.01)\end{array}$ & $\begin{array}{c}23.1 \\
(0.91)\end{array}$ & $\begin{array}{c}19.8 \\
(0.77)\end{array}$ & $\begin{array}{c}20.5 \\
(0.81)\end{array}$ & $\begin{array}{c}21.6 \\
(0.84)\end{array}$ & $\begin{array}{c}24.1 \\
(0.94)\end{array}$ & $\begin{array}{c}24.2 \\
(0.95)\end{array}$ & $\begin{array}{c}24.8 \\
(0.98)\end{array}$ & $\begin{array}{c}25.0 \\
(1.02)\end{array}$ & $\begin{array}{c}23.3 \\
(0.92)\end{array}$ \\
\hline $\begin{array}{c}\mathrm{Mg}^{2+} \\
\left(\mathrm{Mg}^{2+} / \theta\right)\end{array}$ & $5.1(0.21)$ & $\begin{array}{c}4.8 \\
(0.19)\end{array}$ & $\begin{array}{c}4.4 \\
(0.17)\end{array}$ & $\begin{array}{c}5.3 \\
(0.20)\end{array}$ & $\begin{array}{c}5.1 \\
(0.20)\end{array}$ & $\begin{array}{c}5.2 \\
(0.20)\end{array}$ & $\begin{array}{c}6.6 \\
(0.26)\end{array}$ & $\begin{array}{c}6.6 \\
(0.26)\end{array}$ & $\begin{array}{c}6.7 \\
(0.26)\end{array}$ & $\begin{array}{c}6.8 \\
(0.28)\end{array}$ & $\begin{array}{c}5.7 \\
(0.22)\end{array}$ \\
\hline $\begin{array}{c}\mathrm{Al}^{3+} \\
\left(\mathrm{Al}^{3+} / \theta\right)\end{array}$ & $\begin{array}{c}0.3 \\
(0.01)\end{array}$ & $\begin{array}{l}0.1 \\
(0)\end{array}$ & ND & ND & ND & ND & ND & ND & ND & ND & - \\
\hline \multicolumn{12}{|l|}{ Anions $\left[\mathrm{mg} \cdot \mathrm{l}^{-1}\right]$} \\
\hline $\begin{array}{c}\mathrm{Cl}^{-} \\
\left(\mathrm{Cl}^{-} / \theta\right)\end{array}$ & $\begin{array}{c}75.3 \\
(3.10)\end{array}$ & $\begin{array}{c}53.5 \\
(2.16)\end{array}$ & $\begin{array}{c}43.8 \\
(1.72)\end{array}$ & $\begin{array}{c}58.8 \\
(2.28)\end{array}$ & $\begin{array}{c}56.2 \\
(2.21)\end{array}$ & $\begin{array}{c}55.2 \\
(2.16)\end{array}$ & $\begin{array}{c}67.0 \\
(2.61)\end{array}$ & $\begin{array}{c}67.1 \\
(2.62)\end{array}$ & $\begin{array}{c}65.2 \\
(2.57)\end{array}$ & $\begin{array}{c}63.4 \\
(2.59)\end{array}$ & $\begin{array}{l}60.5 \\
(2.4)\end{array}$ \\
\hline $\begin{array}{c}\mathrm{NO}_{3}^{-} \\
\left(\mathrm{NO}_{3}^{-} / \theta\right)\end{array}$ & $\begin{array}{c}44.3 \\
(1.82)\end{array}$ & $\begin{array}{c}27.1 \\
(1.09)\end{array}$ & $\begin{array}{c}20.9 \\
(0.82)\end{array}$ & $\begin{array}{c}19.5 \\
(0.76)\end{array}$ & $\begin{array}{c}19.3 \\
(0.76)\end{array}$ & $\begin{array}{c}19.1 \\
(0.75)\end{array}$ & $\begin{array}{c}20.8 \\
(0.81)\end{array}$ & $\begin{array}{c}20.8 \\
(0.81)\end{array}$ & $\begin{array}{c}21.7 \\
(0.85)\end{array}$ & $\begin{array}{c}20.2 \\
(0.82)\end{array}$ & $\begin{array}{c}23.4 \\
(0.93)\end{array}$ \\
\hline $\begin{array}{c}\mathrm{SO}_{4}^{2-} \\
\left(\mathrm{SO}_{4}^{2-} / \theta\right)\end{array}$ & $\begin{array}{c}33.2 \\
(1.36)\end{array}$ & $\begin{array}{c}24.2 \\
(0.98)\end{array}$ & $\begin{array}{c}23.2 \\
(0.91)\end{array}$ & $\begin{array}{c}21.0 \\
(0.81)\end{array}$ & $\begin{array}{c}20.8 \\
(0.82)\end{array}$ & $\begin{array}{c}21.2 \\
(0.83)\end{array}$ & $\begin{array}{c}20.9 \\
(0.81)\end{array}$ & $\begin{array}{c}21.0 \\
(0.82)\end{array}$ & $\begin{array}{c}21.4 \\
(0.84)\end{array}$ & $\begin{array}{c}20.6 \\
(0.84)\end{array}$ & $\begin{array}{c}22.7 \\
(0.90)\end{array}$ \\
\hline $\begin{array}{c}\mathrm{HPO}_{4}^{2-} \\
\left(\mathrm{HPO}_{4}^{2-} / \theta\right)\end{array}$ & ND & ND & ND & ND & ND & ND & ND & ND & ND & ND & - \\
\hline
\end{tabular}


Table 2. Chemical properties of the soil water extract of the Roman paleosols at the date of sampling (sample period 2009/ 10) (ND, not detectable).

\begin{tabular}{|c|c|c|c|c|c|c|c|c|c|}
\hline Date of sampling & $\begin{array}{c}\text { 2-Feb } \\
2010\end{array}$ & $\begin{array}{c}\text { 18-Feb } \\
2010\end{array}$ & $\begin{array}{c}\text { 2-Mar } \\
2010\end{array}$ & $\begin{array}{c}\text { 18-Mar } \\
2010\end{array}$ & $\begin{array}{c}\text { 1-Apr } \\
2010\end{array}$ & $\begin{array}{l}\text { 15-Apr } \\
2010\end{array}$ & $\begin{array}{l}\text { 29-Apr } \\
2010\end{array}$ & $\begin{array}{c}\text { 13-May } \\
2010\end{array}$ & $\begin{array}{c}\text { Arithmetic } \\
\text { mean }\end{array}$ \\
\hline $\mathrm{pH}$ & 7.4 & 7.8 & 7.7 & 7.7 & 7.8 & 7.8 & 7.8 & 7.8 & 7.7 \\
\hline $\begin{array}{c}\mathrm{EC}_{\text {calc }}\left[\mu \mathrm{S} \cdot \mathrm{cm}^{-1}\right] \\
\text { at } 25^{\circ} \mathrm{C}\end{array}$ & 528.2 & 495.3 & 465.0 & 470.1 & 478.2 & 498.9 & 489.3 & 502.1 & 490.9 \\
\hline \multicolumn{10}{|l|}{ Cations $\left[\mathrm{mg} \cdot \mathrm{I}^{-1}\right]$} \\
\hline $\mathrm{Ca}^{2+}$ & 50.3 & 46.3 & 40.2 & 40.8 & 41.3 & 45.7 & 46.0 & 46.8 & 44.7 \\
\hline $\mathrm{K}^{+}$ & 46.7 & 42.3 & 39.7 & 40 & 41 & 40.7 & 40.5 & 40.8 & 41.5 \\
\hline $\mathrm{Na}^{+}$ & 18.3 & 20.4 & 21.4 & 21.9 & 22 & 23.8 & 22.5 & 24.6 & 21.9 \\
\hline $\mathrm{Mg}^{2+}$ & 6.9 & 7 & 6.7 & 6.72 & 6.75 & 6.8 & 6.7 & 6.8 & 6.8 \\
\hline $\mathrm{Al}^{3+}$ & 0.2 & 0.1 & ND & ND & ND & ND & ND & ND & - \\
\hline \multicolumn{10}{|l|}{ Anions $\left[\mathrm{mg} \cdot \mathrm{I}^{-1}\right]$} \\
\hline $\mathrm{Cl}^{-}$ & 70.3 & 60.2 & 58.3 & 58.7 & 60.2 & 62.3 & 61.5 & 61.9 & 61.7 \\
\hline $\mathrm{NO}_{3}^{-}$ & 38.7 & 39.6 & 37.5 & 37.9 & 38 & 38.4 & 39.0 & 38.7 & 38.5 \\
\hline $\mathrm{SO}_{4}^{2-}$ & 32.7 & 33.5 & 30.8 & 31.1 & 32 & 32.5 & 31.6 & 31.8 & 32.0 \\
\hline $\mathrm{HPO}_{4}^{2-}$ & 1.1 & 0.7 & 0.5 & 0.5 & 0.6 & 0.7 & 0.6 & 0.7 & 0.68 \\
\hline
\end{tabular}

be detected. Moreover, no $\mathrm{HPO}_{4}^{2-}$ ions could be determined in the soil water extract.

The amount of water available in the soil has a distinct influence on the liquid phase chemistry in terms of concentration or dilution effects during dry or wet conditions, respectively (Mengel and Kirkby, 2001 [44]). Consequently, to gain a corrected course of the soil water composition, $\mathrm{EC}_{\text {calc }}$ and the cation and anion concentrations were devided by the soil moisture $(\theta)$ of the pre-AD 79 paleosol at the date of sampling. However, due to the relative small variation of $\theta$ during the sample period of only $1.5 \%$ the course of soil water composition does not change significantly. ECcalc/ $\theta$ has its maximum at the first soil solution sampling end of December 2008 and decreases for the first four weeks until the end of January 2009. In March it increases, stagnates and again slightly increases at the very end of the sample period. The increased ECalc/ $\theta$ ratio during the first weeks of soil water sampling coincides with increased ion concentrations. In the middle of the rainy winter season ECcalc/ $\theta$ reaches its minimum. Thereafter, ECcalc/ $\theta$ increases at the end of March and slightly at the end of April on account of an increase of $\mathrm{Ca}^{2+}, \mathrm{Cl}^{-}$and partly of $\mathrm{Na}^{+}$.

During the winter season of 2009/10 the above described characteristics of the soil water chemistry of the pre-AD 79 paleosol recurred. The ion concentration is increased at the beginning, then decreases to its minimum in the middle of the sample period and re-increases at its end (Table 2). Even though the mean ion concentrations have slightly increased in 2009/10 compared to the previous sampling season, the relative proportions have not changed. Hence, the fact that in 2009/10 very small amounts of phosphate anions were detected in the soil water extract most likely results from that general trend. The reason for that slight increase is not known, however, it is not relevant for the present study.

Unfortunately, in autumn 2009 all three soil moisture sensors failed as they probably lost their attachment to the substrate possibly due to soil shrinkage during the dry summer season. Consequently, the ion concentrations could not be corrected for $\theta$ which would have even amplified the course of soil water chemistry to a small extent as it did in 2008/09.

\subsection{Soil Solid Phase}

Tables 3 and 4 show the results of the soil solid phase analysis for the modern soils and the associated pre-AD 79 paleosols. Only when a soil parameter shows the same trend in all four pairs of soils, we assumed this to be the result of post-burial effects. 
Table 3. Soil solid phase properties of the pre-AD 79 Roman paleosols and modern soils near Pompeii I.

\begin{tabular}{|c|c|c|c|c|c|c|c|c|c|c|c|c|}
\hline \multirow[b]{2}{*}{ Site } & \multirow[b]{2}{*}{ Soil } & \multirow[b]{2}{*}{ Soil texture } & \multirow[b]{2}{*}{$\begin{array}{c}\text { Munsell } \\
\text { soil colour }\end{array}$} & \multirow[b]{2}{*}{$\underset{\left(\mathrm{CaCl}_{2}\right)}{\mathrm{pH}}$} & \multirow[b]{2}{*}{$\begin{array}{l}\mathrm{CaCO}_{3} \\
{\left[\mathrm{~g}^{2} \cdot \mathrm{kg}^{-1}\right]}\end{array}$} & \multirow[b]{2}{*}{$\begin{array}{c}\text { TOC } \\
{\left[\mathbf{g}^{\prime} \cdot \mathrm{kg}^{-1}\right]}\end{array}$} & \multirow[b]{2}{*}{$\begin{array}{c}\mathrm{N} \\
{\left[\mathrm{g} \cdot \mathrm{kg}^{-1}\right]}\end{array}$} & \multirow[b]{2}{*}{$\begin{array}{c}\text { CEC } \\
{\left[\mathrm{mmol}_{\mathrm{c}} \cdot \mathrm{kg}^{-1}\right]}\end{array}$} & \multicolumn{4}{|c|}{ Exchangeable cations $\left[\mathrm{mmol}_{\mathrm{c}} \cdot \mathrm{kg}^{-1}\right]$} \\
\hline & & & & & & & & & $\mathbf{K}$ & $\mathrm{Na}$ & Ca & Mg \\
\hline \multirow{2}{*}{ DAI16 } & $\begin{array}{c}\text { modern } \\
\text { soil }\end{array}$ & Loamy sand & 10YR3/1 & 6.0 & 7.1 & 11.6 & 1.1 & 139.0 & 20.7 & 48.7 & 52.2 & 17.1 \\
\hline & $\begin{array}{c}\text { pre-AD } 79 \\
\text { paleosol }\end{array}$ & Sandy loam & 10YR4/2 & 7.1 & 7.9 & 8.9 & 0.8 & 140.2 & 20.3 & 13.2 & 94.7 & 11.7 \\
\hline \multirow{2}{*}{ DAI18 } & $\begin{array}{c}\text { modern } \\
\text { soil }\end{array}$ & Sandy loam & 10YR3/1 & 7.4 & 30.8 & 8.0 & 0.5 & 66.0 & 19.0 & 10.4 & 32.7 & 3.4 \\
\hline & $\begin{array}{c}\text { pre-AD } 79 \\
\text { paleosol }\end{array}$ & Sandy loam & 10YR4/2 & 7.5 & 16.2 & 3.4 & 0.1 & 172.2 & 16.3 & 6.6 & 138.5 & 10.7 \\
\hline \multirow{2}{*}{ VdM } & $\begin{array}{l}\text { modern } \\
\text { soil }\end{array}$ & Loamy sand & 10YR3/2 & 6.8 & 2.7 & 14.3 & 1.4 & 216.9 & 33.6 & 5.6 & 164.0 & 14.3 \\
\hline & $\begin{array}{c}\text { pre-AD } 79 \\
\text { paleosol }\end{array}$ & Sandy loam & 10YR4/3 & 7.7 & 4.0 & 3.1 & 0.3 & 222.9 & 22.1 & 8.3 & 177.1 & 15.1 \\
\hline \multirow{2}{*}{ VdR } & $\begin{array}{c}\text { modern } \\
\text { soil }\end{array}$ & Loamy sand & 10YR3/1 & 5.8 & 0.5 & 16.3 & 2.6 & 107.5 & 6.3 & 7.7 & 83.8 & 9.7 \\
\hline & $\begin{array}{c}\text { pre-AD } 79 \\
\text { paleosol }\end{array}$ & Sandy loam & 10YR3/1 & 8.7 & 0.2 & 6.0 & 1.7 & 183.5 & 18.8 & 26.7 & 125.2 & 12.7 \\
\hline
\end{tabular}

Table 4. Soil solid phase properties of the pre-AD 79 Roman paleosols and modern soils near Pompeii II.

\begin{tabular}{|c|c|c|c|c|c|c|c|c|c|c|}
\hline \multirow[b]{2}{*}{ Site } & \multirow[b]{2}{*}{ Soil } & \multirow[b]{2}{*}{$\begin{array}{c}\mathbf{K}_{\text {tot }} \\
{\left[g^{-1} \cdot \mathbf{k g}^{-1}\right]}\end{array}$} & \multirow[b]{2}{*}{$\underset{\left[g^{2} \cdot k^{-1}\right]}{\left.N^{-1}\right]}$} & \multirow[b]{2}{*}{$\underset{\left[g^{-} \cdot \mathbf{k g}^{-1}\right]}{\mathbf{C a}_{\text {tot }}}$} & \multirow[b]{2}{*}{$\underset{\left[g^{\prime} \cdot \mathbf{k g}^{-1}\right]}{\mathbf{M g}_{\text {tot }}}$} & \multirow[b]{2}{*}{$\mathrm{CEC}_{\text {pot }}$ ratio } & \multicolumn{4}{|c|}{ Nutrient ratio } \\
\hline & & & & & & & $\frac{K_{\text {exch }}}{K_{\text {tot }}}$ & $\frac{\mathrm{Na} \text { exch }}{\mathrm{Na}}$ & $\frac{\text { Caexch }}{C a_{\text {tot }}}$ & $\frac{M g_{\text {exch }}}{M g_{\text {tot }}}$ \\
\hline \multirow{2}{*}{ DAI16 } & $\begin{array}{l}\text { modern } \\
\text { soil }\end{array}$ & 37.4 & 12.8 & 29.2 & 11.4 & 0.16 & 0.55 & 3.80 & 1.79 & 1.50 \\
\hline & $\begin{array}{c}\text { pre-AD } 79 \\
\text { paleosol }\end{array}$ & 25.8 & 8.4 & 31.7 & 9.2 & 0.16 & 0.79 & 1.57 & 2.99 & 1.27 \\
\hline \multirow{2}{*}{ DAI18 } & $\begin{array}{l}\text { modern } \\
\text { soil }\end{array}$ & 38.6 & 13.5 & 38.2 & 13.1 & 0.07 & 0.49 & 0.77 & 0.86 & 0.26 \\
\hline & $\begin{array}{c}\text { pre-AD } 79 \\
\text { paleosol }\end{array}$ & 33.2 & 16.7 & 30.3 & 8.3 & 0.15 & 0.49 & 0.40 & 4.57 & 1.29 \\
\hline \multirow{2}{*}{ VdM } & $\begin{array}{c}\text { modern } \\
\text { soil }\end{array}$ & 37.3 & 11.9 & 31.6 & 9.7 & 0.24 & 0.90 & 0.47 & 5.19 & 1.47 \\
\hline & $\begin{array}{c}\text { pre-AD } 79 \\
\text { paleosol }\end{array}$ & 15.0 & 9.8 & 23.0 & 6.4 & 0.29 & 1.47 & 0.85 & 7.70 & 2.36 \\
\hline \multirow{2}{*}{ VdR } & $\begin{array}{c}\text { modern } \\
\text { soil }\end{array}$ & 35.4 & 10.7 & 32.5 & 10.5 & 1.21 & 0.18 & 0.72 & 2.58 & 0.92 \\
\hline & $\begin{array}{c}\text { pre-AD } 79 \\
\text { paleosol }\end{array}$ & 21.1 & 6.6 & 23.2 & 7.8 & 3.13 & 0.89 & 4.05 & 5.40 & 1.63 \\
\hline
\end{tabular}

The modern soils are well penetrated by roots and soil fauna and generally appear loosely structured. In contrast, the paleosols have a massive structure with little recognizable macro porosity. The mean bulk density of the paleosols is $1.4 \mathrm{~g} / \mathrm{cm}^{3}$ and that of the modern soils is $1.1 \mathrm{~g} / \mathrm{cm}^{3}$. The Munsell soil colour (on moist samples) of the modern soils is very dark gray and that of the paleosols is dark grayish brown. The $\mathrm{pH}$ values of the modern soils are between 5.8 and 7.4 and of the paleosols between 7.1 and 8.7. Furthermore, in contrast to the modern soils, in the paleosols the $\mathrm{pH}$ value is not consistently increasing with increasing depth. The CEC ratios (Equation (2)) of the paleosols are higher compared to the modern soils. This coincides with higher nutrient ratios (Equation (3)) for Ca and K. The modern soils have low to moderate soil organic matter (SOM) contents whereas in the pre-AD 79 paleosols it is very low to low. This corresponds to amounts of total organic carbon (TOC) of 8 to $16.3 \mathrm{~g} \cdot \mathrm{kg}^{-1}$ for the modern soils and 3.1 to $8.9 \mathrm{~g} \cdot \mathrm{kg}^{-1}$ for the paleosols. Accordingly, nitrogen ranges between 0.5 and 2.6 in the modern soils and between 0.1 and 1.7 in the paleosols. 


\section{Discussion}

\subsection{Groundwater Table}

As mentioned above, after AD 79 the groundwater table increased by about $1.8 \mathrm{~m}$. To some extent, this can be an indirect result of the AD 79 eruption. The burial of the Sarno River plain is believed to have left a bare landscape free of vegetation and covered with unconsolidated volcanic material. Consequently, due to these unstable conditions especially the surrounding steep mountain slopes were vulnerable to severe erosion processes during intense rainfall events causing debris flows and landslides (Cinque et al., 2000 [45]; Cinque and Robustelli, 2009 [46]). Even though the AD 79 pumice lapilli layer show a very high hydraulic conductivity, the above PDC deposits consist of fine tephra that, together with intense rainfall, can generate infiltration excess overland flow and thus erosion. Erosion and the destruction of the vegetation cover cause a reduction of the water retention capacity which, in turn, results in increased runoff and an increasing groundwater table in the adjacent river plain (Vogel and Märker, 2012 [18]). The latter may also be caused by the accelerated deforestation and the clearance of the natural vegetation since the Middle Ages (around 700 BP, see Schneider, 1985 [47]; Buccheri et al., 2002 [41]; Russo Ermolli and di Pasquale, 2002 [48]).

Considering this groundwater rise, the Sarno River plain must be divided into two different zones of potential post-burial soil developments:

1) the lower areas of the inner Sarno River plain where after AD 79 the originally terrestrial pre-AD 79 paleosol has come under the influence of a rising groundwater table; and

2) the higher areas of the Sarno River plain where the paleosol is still part of the vadose zone and more likely influenced by vertical or lateral soil water flow.

This demonstrates that the mechanism of post-burial soil developments being active in the pre-AD 79 paleosols is by no means uniform for the entire Sarno River plain but strongly depends on the paleotopography and the paleolandscape position.

Vogel and Märker, 2012 [18], studied the effect of the post-burial groundwater rise on the originally terrestrial pre-AD 79 paleosols. Under the present-day influence of groundwater dynamics the paleosols are characterised by: 1) higher amounts of organic carbon and nitrogen; 2) a darker Munsell colour of the buried topsoil; 3) lower amounts of calcium carbonate; 4) increased sulphate concentrations together with a decreased $\mathrm{pH}$ value; and 5) redoximorphic features in the overlying $\mathrm{AD} 79$ pumice fallout layer.

\subsection{Soil Liquid Phase}

\subsubsection{Soil Water Flow}

Figure 4 illustrates that, at Villa Regina, the soil water needed about one month to percolate from the presentday surface to the pre-AD 79 paleosol in a depth of $8 \mathrm{~m}$. That delay results from the fact that the overlying volcanic ash and pumice layers as well as the volcanic soils have a large water retention capacity (Shoji and Takahashi, 2002 [49]; Sahin et al., 2005 [50]). Moreover, as earlier mentioned, the stratigraphy overlying the pre-AD 79 paleosol at Villa Regina consists of a sequence of pyroclastic material, fluvial deposits and soil substrates showing different soil textural characteristics. In unsaturated multi-layered soil profiles water movement is not necessarily strictly vertical but considerably influenced by the stratification effect. Especially less permeable fine grained layers, like ash layers or soils interbedded in highly permeable pumice layers or fluvial deposits tend to induce unsteady flow patterns. Water is held in the finer material and does not percolate further down into coarser material until the former layer is saturated. Finally, not until the water potential of the two strata reach the same value the water movement is again controlled by the gravitational potential (Fiorillo and Wilson, 2004 [51]; Javaux and Vanclooster, 2004 [52]).

Soil water could be extracted from the paleosol in a four months period between the end of December 2008 and the end of April 2009. The paleosol required a approximate soil moisture of more than about $24.5 \%$ for mobile gravitational water to be available and to be extracted by the suction cups with the applied tension of 550 mbar. In contrast, when $\theta$ is below $24.5 \%$ the matric potential attracting the soil water to the mineral soil particles is increased and exceeds the tension of the suction cups.

These above mentioned results verify that a soil water flow from the overlying volcanic deposits into the preAD 79 paleosol does take place as it was assumed by Foss, 1988 [9], Foss et al., 2002 [10] and Inoue et al., 2009 [11]. However, it only occurs during the rainy winter period and, under the stratigraphic conditions at Villa Regina, with a delay of about one month. 
In contrast to the pre-AD 79 paleosol no soil water could be extracted from the AD 79 pumice lapilli fallout directly above. This could be due to the following two reasons. Firstly, the porosity of the pumice layer has a bimodal structure. On one hand the pumice lapilli has a very coarse texture with a lot of external macropores between the clasts. On the other hand each pumiceous particle consists of a very fine internal porous system. Thus, the water may not move homogeneously through the pumice layer. In the macropores between the clasts it randomly follows preferential flow paths until it is absorbed by the pumiceous particles showing a high water retention capacity (Sahin et al., 2005 [50]). Hence, the first infiltration water after a dry summer season is expected to be absorbed by the pumice and almost no gravitational water flow may be extracted by the suction cups from the external macropores until the particles reach saturation point. Secondly, the preferential flow through the pumice layer is often restricted to a small fraction of the total macropore volume. Thus, the suction cups were simply not able to capture such a preferential flow path. However, the fact that soil water could be extracted from the pre-AD 79 paleosol underneath proves that water flow does take place, either vertically by infiltration or laterally by interflow. Infact, interflow on top of the pre-AD 79 paleosurface can also result in a "moist" paleosol but a "dry" pumice layer directly above when upslope water percolates through the pumice and laterally enters the paleosol. Interflow upon the pre-AD 79 soil surface is caused by the strong decrease of permeability at the transition from the AD 79 pumice layer to the pre-AD 79 paleosol. Hood infiltrometer measurements of saturated hydraulic conductivity $\left(\mathrm{K}_{\mathrm{sat}}\right)$ yielded $\mathrm{K}_{\mathrm{sat}}$ values of around $0.005 \mathrm{~cm} \cdot \mathrm{s}^{-1}$ for the paleosol. In contrast, $\mathrm{K}_{\mathrm{sat}}$ of the white pumice layer was beyond instrumentation range of the hood infiltrometer $(>0.01 \mathrm{~cm}$. $\mathrm{s}^{-1}$ ). Hence, it was minimum one order of magnitude higher compared to the paleosol (Vogel and Märker, 2011 [53]).

\subsubsection{Soil Water Chemistry}

The analysis of the soil water chemistry at Villa Regina showed that the dominant cation percolating into the pre-AD 79 paleosol is calcium. Despite the high concentration of $\mathrm{Cl}^{-}$, the relatively low $\mathrm{EC}_{\text {calc }}$ of the soil water extract reveals that the pre-AD 79 paleosol can be considered non-saline (Schoeneberger et al., 2002 [54]). However, due to the relative vicinity of the study area to the Tyrrhenian Sea high amounts of $\mathrm{Cl}^{-}$and $\mathrm{Na}^{+}$in the lysimeter extract may result from dry deposition of sea water aerosols during onshore winds (Scheffer and Schachtschabel, 2010 [24]). Nitrate may rather derive from anthropogenic sources. This corresponds with finding of Adamo et al., 2007 [55], who found increased amounts of $\mathrm{NO}_{3}^{-}$in aquifers of the Sarno River plain due to intensive agricultural use. During the first two weeks of the sampling period very small amounts of aluminium were detected at slightly alkaline $\mathrm{pH}$ values of the soil water extracts. This seems to be an artefact of the sampling or analysis procedure. In fact, finely dispersed colloidal Al may have entered the soil solution sample by passing the membrane of the suction cups and at some stage between $\mathrm{pH}$ and $\mathrm{Al}$ measurement had the opportunity to be dissolved to $\mathrm{Al}^{3+}$ (Wolt, 2014, written communication; see Kennedy et al., 1974 [56]; Laxen and Chandler, 1982 [57]). However, the subsequent absence of free $\mathrm{Al}$ indicates that no soil acidification is active within the pre-AD 79 paleosol which agrees with the slightly alkaline $\mathrm{pH}$ of the soil water. Finally, the fact that no $\mathrm{HPO}_{4}^{2-}$ ions could be detected in the soil water extract is due to its weak solubility and usually strong retention by the soil solid phase and soil organic matter (Wolt, 1994 [7]). Furthermore, the retention of phosphate in a soil is $\mathrm{pH}$-dependent leaving it more soluble at a slightly acid to moderately acid $\mathrm{pH}$ value. At alkaline $\mathrm{pH}$ on the other hand its solubility is reduced by the formation of Ca-phosphates (Welp et al., 1983 [58]).

The course of the soil water chemistry revealed increased ion concentrations at the beginning and at the end of the sample period. This can be explained by the "first flush effect" that can occur at the beginning of the rainy season when the first infiltration water reaches the pre-AD 79 paleosol after a dry summer season. An accumulation of ions during summer then results in higher element concentrations in the soil water extract. Arthur and Fahey, 1993 [37], observed the same effect but associated with snowmelt instead of precipitation water. At the initial stages of snowmelt the solute concentrations in the soil solution were also high and declined rapidly in the first four to six weeks.

It is striking that the "first flush effect" is much stronger for the anions than for the cations. This may be due to the fact that volcanic soils have a high fraction of variable charge (Madeira et al., 2007 [59]). Consequently, at a slightly alkaline $\mathrm{pH}$ value the net surface charge is negative resulting in a high cation exchange capacity and a negligible anion exchange capacity. This is particularly important for the retention and leaching of cations and anions (Nanzyo et al., 1993 [60]; Madeira et al., 2007 [59]). Hence, at slightly alkalkine pH, cations tend to be adsorbed to the surface of the soil colloids whereas anions are rather leached out of the profile by the mobile soil 
water. In the middle of the rainy winter season the ion concentrations reach their minimum because of continuous leaching from the soil (De Pascale and Barbieri, 1997 [61]). At the end of the sample period the ion concentrations start to reincrease. This is caused by the inversion of the "first flush effect", i.e. the decline of ion leaching from the soil and its accumulation due to a smaller amount of mobile soil water at the end of the rainy season (De Pascale and Barbieri, 1997 [61]). However, this effect is much less pronounced compared to the beginning of the sample period, probably due to retention effects of the soil matrix as well as a much slower decrease of precipitation at the end of the rainy season in contrast to a steep and fast increase at the beginning (Wagner, 1967 [62].

Beyond the described "first flush effect" no significant seasonal variation could be detected in the soil water chemistry. This may be due to the following reasons:

1) In the pre-AD 79 paleosol at about $8 \mathrm{~m}$ depth plants are absent. Thus, there is no influence on the soil water composition by nutrient uptake and ion secretion of plant roots;

2) The mobile soil water fraction predominantly sampled by tension lysimeters has much shorter contact times with the soil solid phase compared to capillary water. This results in lower ion concentrations and less seasonality (Wolt, 1994 [7]);

3) Since soil water could only be extracted from the paleosol in a short period of four months, there was no seasonal variation in the soil water composition.

\subsection{Soil Solid Phase}

From the relative stratigraphic position of the pre-AD 79 paleosols and the modern soils and by comparison with the eruption history of Somma-Vesuvius an estimation of their approximate soil age was made. With respect to the paleosols, the total soil age has to be subdivided into two main soil development periods, i.e. the duration of pre-burial and post-burial soil development. The parent volcanic material at Boscoreale (VR) and Pompeii (VdM) can most likely be ascribed to the Avellino eruption or the following AP1/AP2 eruption (3450 - 3000 BP; Andronico and Cioni, 2002 [63] and references therein). At Scafati (VdR) the pre-AD 79 paleosol developed from the later AP eruption products of Somma-Vesuvius (AP3 - AP6) which were dated between $2.710 \pm 60$ BP (Rolandi et al., 1998 [64]) and 217 BC (Stothers and Rampino, 1983 [65]; Rolandi et al., 1998 [64]). Consequently, the pre-burial age of the pre-AD 79 paleosols, i.e. the time they developed upon the ancient land surface, ranges between 1050 and 1500 years for Boscoreale and Pompeii and between 300 and 800 years for Scafati. In contrast, the post-burial soil age of all pre-AD 79 paleosols is approximately 1900 years. Thus, they existed for a much longer period of time under buried than under unburied conditions. This fact demonstrates the necessity to critically evaluate the possibility of post-burial soil developments in the paleosols before drawing conclusions on their ancient soil characteristics. Considering both, pre-burial and post-burial duration, the total soil age of the pre-AD 79 paleosols can be estimated between 2200 and 3400 years. According to its tephrostratigraphic position the age of the modern soils is between 1300 and 1900 years as they are underlain by the pyroclastic fallout of a medieval eruption of Somma-Vesuvius (DAI16, VdM, VdR) and reworked ash layers of the final stage of the AD 79 eruption (DAI18).

The results of the soil solid phase analysis show distinct characteristics that distinguish the topsoils of the buried pre-AD 79 paleosols from the unburied modern soils at the same topographic location. The paleosols have a $\mathrm{pH}$ value that is more than one unit higher compared to the modern soils. This corresponds with the observations of Foss, 1988 [9], Foss et al., 2002 [10] and Inoue et al., 2009 [11]. The lower pH values of the modern soils most likely result from:

1) Active accumulation and decomposition of soil organic matter (SOM) producing organic acids;

2) Nutrient uptake and proton release of plant roots;

3) Acid deposition from the atmosphere (acid rain); and

4) Leaching of basic cations from the upper horizons by percolating soil water.

In contrast, the results of the soil liquid phase study verify that the pre-AD 79 paleosols are rather subject to post-burial nutrient input by leaching from the overlying deposits which increased their $\mathrm{pH}$ value. This confirms the earlier mentioned assumption of Foss, 1988 [9], Foss et al., 2002 [10] and Inoue et al., 2009 [11]. However, as described above this process only takes place during the rainy winter season when mobile soil water is present. Furthermore, in the paleosols the $\mathrm{pH}$ decreasing influence of plants and active accumulation of SOM is missing. 
It was determined that the $\mathrm{pH}$ of the paleosols often does not consistently increase with depth as can be seen for most of the modern unburied soils. After burial, the former A-horizons of the paleosols are subject to ion accumulations from the overlying strata. Hence, the boundaries between zones of leaching and accumulation can gradually blur (Holliday, 2004 [66]).

The post-burial nutrient accumulation in the paleosols also results in higher CEC ratios compared to the modern soils. With regard to the nutrient ratios only $\mathrm{Ca}$ and $\mathrm{K}$ are clearly enriched in the paleosols. Hence, $\mathrm{Ca}$ and $\mathrm{K}$ seem to be the dominant base cations to be transported through the profile which is congruent with the results from the soil water analysis. This only partly corresponds to Foss, 1988 [9] and Foss et al., 2002 [10], who presumed that especially $\mathrm{Ca}^{2+}$ and $\mathrm{Mg}^{2+}$ leach from the overlying volcanic sediments and recharge the surface horizons of the paleosols. Due to the neutral to slightly alkaline $\mathrm{pH}$ value of the pre-AD 79 paleosols the surface charge of the soil colloids is expected to be predominantly negative. Thus, adsorption of anions to the exchange sites of the paleosols is negligible. Hence, they are rather leached out of the soil profile.

The soil organic matter (SOM) contents are low to moderate for the modern soils and very low to low for the paleosols. Thus, the amount of organic carbon (TOC) is approximately $7 \mathrm{~g} \cdot \mathrm{kg}^{-1}$ lower in the paleosols. Macroscopically, this agrees with a Munsell soil colour (on moist samples) having higher value and chroma, i.e. very dark gray compared to dark grayish brown. According to TOC, the paleosols also contain lower amounts of nitrogen than the modern soils. The decreased concentrations of TOC and N in the paleosols may be due to postburial decomposition of SOM. With burial in AD 79 the accumulation of SOM within the paleosols has stopped. As the AD 79 pumice fallout layer covering the pre-AD 79 paleosols is well aerated no air exclusion took place. Hence, microbial activity to gradually decompose SOM is not stopped even though it may have slowed down. This is supported by Crowther et al., 1996 [1], who studied post-burial change in a humic rendzina soil in England. They state that decomposition reduced the amounts of TOC by about $29 \%$ in only 32 years after burial. Only in extremely anaerobic conditions SOM may be preserved from decomposition after burial (see Dimbleby, 1984 [67]). Hence, Crowther et al., 1996 [1], conclude that the present-day concentrations of TOC in the buried soils are not reflecting their original SOM status.

In the Sarno River plain, a second reason for reduced amounts of TOC in the paleosols may be due to interaction with hot volcaniclastic fallout during the AD 79 eruption. To some extent, heating of the pre-AD 79 paleosols during contact with the AD 79 pumice fallout may have caused sublimation of SOM. Thomas and Sparks, 1992 [68], modelled the process of tephra cooling during fallout from eruption columns. They found that the heat loss of clasts decreases with increasing grain size and decreasing fall height. Whereas smaller clasts are deposited cold, they conclude that larger clasts of Plinian fallout can retain enough heat to pose hazards to life and property by igniting fires.

Finally, soil structure and bulk density of the modern soils and the pre-AD 79 paleosols are used as an indicator of soil compaction. Already from the macroscopic comparison of the two soils it is evident that the pre-AD 79 paleosols show a massive soil structure with little recognizable secondary porosity, i.e. structure-dependent porosity. This may result from: 1) the superimposed load of 3.3 (VdR) to $8 \mathrm{~m}(\mathrm{VR})$ of overlying post-AD 79 deposits; 2) the absence of root penetration; and 3) the reduction of active soil biota such as earthworms. However, as shown by the soil moisture and hydraulic conductivity measurements, no waterlogging occurred in the paleosols as the texture-dependent primary porosity of the sandy loam still permits soil water movement. In contrast to the paleosols, the unburied modern soils are well penetrated by roots and soil fauna and generally appear more loosely structured. This is in accordance with a slightly increased mean bulk density of $1.4 \mathrm{~g} / \mathrm{cm}^{3}$ for the pre-AD 79 paleosols compared to $1.1 \mathrm{~g} / \mathrm{cm}^{3}$ for the modern soils.

\section{Conclusions}

A soil liquid and solid phase analysis was carried out in the pre-AD 79 Roman paleosols around Pompeii to estimate potential post-burial soil development. The combination of the present-day mean groundwater table of the Sarno River plain (Autorità di Bacino del Sarno) with the pre-AD 79 topography (Vogel et al., 2011 [15]) revealed that, in terms of post-burial soil developments, one has to subdivide the Sarno River plain into two different zones: 1) at around 37\% of the Sarno River plain the Roman paleosols are influenced by a rise of the mean groundwater table of approximately $1.8 \mathrm{~m}$ since $\mathrm{AD} 79$; and 2) at the remaining $63 \%$ the paleosols are still part of the vadose zone and more likely influenced vertically by infiltration water or laterally by interflow. Consequently, the mechanism of post-burial soil development being active in the pre-AD 79 paleosols is not uniform 
for the entire Sarno River plain but strongly depends on the paleotopographic situation.

The soil moisture and soil liquid phase study at the archaeological excavation of Villa Regina demonstrated that recently soil water flow down to the pre-AD 79 paleosol in a depth of $8 \mathrm{~m}$ takes place. Thus, since AD 79, this soil water can dissolve ions from the overlying volcanic deposits, incorporate them into the paleosol and influence its solid phase properties. However, mobile soil water was only extracted from the paleosol in a four months period when the soil moisture exceeded $24.5 \%$. This restricts the potential influence of post-burial nutrient input to the rainy winter season. The soil liquid phase of the pre-AD 79 paleosol shows a distinct chemical composition. At the beginning and the end of the sample period increased ion concentrations were determined that can be explained by the "first flush effect" and its inversion, respectively.

Through the combination of the soil liquid phase study with the soil solid phase study an estimate of potential post-burial soil changes was made:

1) Leaching of nutrients from overlying deposits and accumulation in the paleosols led to a) higher CEC ratios, b) higher nutrient ratios for $\mathrm{Ca}^{2+}$ and $\mathrm{K}^{+}$, and c) higher $\mathrm{pH}$ values in the paleosols. However, the results from the soil water and soil moisture study restrict the soil water flow to the rainy winter season.

2) Since the buried A-horizon of the paleosols is recently subject to ion accumulations from the overlying strata, former topsoil eluvial horizons gradually turn into subsoil illuvial horizons. This results in a reversion of the depth function of the $\mathrm{pH}$ value.

3) The paleosols show a massive soil structure with little recognizable macro porosity and have a slightly increased bulk density due to burial by several meters of post-AD 79 deposits.

4) Considering the particular conditions during and after burial in $\mathrm{AD} 79$, decreased organic carbon and nitrogen contents and increased $\mathrm{C} / \mathrm{N}$ ratios in the paleosols may derive from decomposition of soil organic matter or sublimation during contact with hot $\mathrm{AD} 79$ pumice fallout.

It can be summarized that deeper insights were gained into the occurrence of mobile soil water within the pre$\mathrm{AD} 79$ paleosols and into the nature of potential post-burial soil developments. In the future, they should be taken into account when pre-AD 79 paleosols are characterised and interpreted with respect to paleoenvironmental conditions. Additionally, the presented results may provide hints regarding the susceptibility and hazard of the groundwater body to contamination by agricultural and industrial pollutants.

\section{Acknowledgements}

This study is part of the interdisciplinary SALVE-research project undertaken by the German Archaeological Institute (DAI) in cooperation with the Heidelberg Academy of Sciences and Humanities (HAW) and the University of Tübingen (www.salve-research.org). Project directors are Florian Seiler (DAI) and Michael Märker (HAW) and it was funded by the Deutsche Forschungsgemeinschaft (German Research Foundation). We would like to thank our local project partners and all their collaborators for their cooperation, particularly the Autorità di Bacino del Sarno and the Soprintendenza Speciale per i Beni Archaeologici di Napoli e Pompei. Particularly we thank Grete Stefani and her team at the archaeological excavation of Villa Regina for their support to install the soil water monitoring system. Special gratitude goes to Maria Teresa Pappalardo for sampling and maintenance as well as to Giovanni Di Maio for conducting the stratigraphic drillings and for his valuable local geological knowledge. Furthermore we would like to thank Peter Kühn, Philipp Hoelzmann, Stefan Wessel-Bothe, Silke Schweighoefer, Jörn Breuer, Yvonne Oelmann and Marc Ruppenthal, ECOLAB G.M. '65 S.R.L. and UABG GmbH for their various technical supports.

\section{References}

[1] Crowther, J., Macphail, R.I. and Cruise, G.M. (1996) Short-Term, Post-Burial Change in a Humic Rendzina Soil, Overton down Experimental Earthwork, Wiltshire, England. Geoarchaeology, 11, 95-117. http://dx.doi.org/10.1002/(SICI)1520-6548(199603)11:2<95::AID-GEA1>3.0.CO;2-4

[2] Retallack, G.J. (1998) Core Concepts of Paleopedology. Quaternary International, 51-52, 203-212. http://dx.doi.org/10.1016/S1040-6182(97)00046-3

[3] Retallack, G.J. (2001) Soils of the Past, an Introduction to Paleopedology. Blackwell Science, Oxford.

[4] French, C. (2003) Geoarchaeology in Action. Studies in Soil Micromorphology and Landscape Evolution. Routledge, London.

[5] Scudder, S.J., Foss, J.E. and Collins, M.E. (1996) Soil Science and Archaeology. Advances in Agonomy, 57, 1-76. 
http://dx.doi.org/10.1016/S0065-2113(08)60922-0

[6] Ugolini, F.C. and Dahlgren, R.A. (1987) The Mechanism of Podzolization as Revealed by Soil Solution Studies. In: Righi, D. and Chauvel, A., Eds., Podzols and Podzolisation (in French), AFES et INRA, Plaisir et Paris, 195-203.

[7] Wolt, J.D. (1994) Soil Solution Chemistry: Applications to Environmental Science and Agriculture. Wiley, New York, $345 \mathrm{p}$.

[8] Snakin, V.V., Prisyazhnaya, A.A. and Kovács-Láng, E. (2001) Soil Liquid Phase Composition. Elsevier, Amsterdam.

[9] Foss, J.E. (1988) Paleosols of Pompeii and Oplontis. In: Curtis, R.L., Ed., Studia Pompeiana and Classica, Aristide D. Caratzas, Publisher, New Rochelle.

[10] Foss, J.E., Timpson, M.E., Ammons, J.T. and Lee, S.Y. (2002) Paleosols of the Pompeii Area. In: Jashemski, W.F., Ed., The Natural History of Pompeii, Cambridge University Press, Cambridge, 65-79.

[11] Inoue, Y., Baasansuren, J., Watanabe, M., Kamei, H. and Lowe, D.J. (2009) Interpretation of Pre-AD 472 Roman Soils from Physicochemical and Mineralogical Properties of Buried Tephric Paleosols at Somma Vesuviana Ruin, Southwest Italy. Geoderma, 152, 243-251. http://dx.doi.org/10.1016/j.geoderma.2009.06.010

[12] Zehetner, F., Miller, W.P. and West, L.T. (2003) Pedogenesis of Volcanic Ash Soils in Andean Ecuador. Soil Science Society of America Journal, 67, 1797-1809. http://dx.doi.org/10.2136/sssaj2003.1797

[13] Agnelli, A.E., Corti, G., Agnelli, A., Del Carlo, P., Coltelli, M. and Ugolini, F.C. (2007) Features of Some Paleosols on the Flanks of Etna Volcano (Italy) and Their Origin. Geoderma, 142, 112-126. http://dx.doi.org/10.1016/j.geoderma.2007.08.003

[14] Vogel, S. and Märker, M. (2010) Reconstruction the Roman Topography and Environmental Features of the Sarno River Plain (Italy) before the AD 79 Eruption of Somma-Vesuvius. Geomorphology, 115, 67-77. http://dx.doi.org/10.1016/j.geomorph.2009.09.031

[15] Vogel, S., Märker, M. and Seiler, F. (2011) Revised Modeling the Post-AD 79 Volcanic Deposits of Somma-Vesuvius to Reconstruct the Pre-AD 79 Topography of the Sarno River Plain (Italy). Geologica Carpathica, 62, 5-16. http://dx.doi.org/10.2478/v10096-011-0001-3

[16] Lulli, L. (2007) Italian Volcanic Soils. In: Arnalf, Ó., Bartoli, F., Buurman, P., Óskarson, H., Stoops, G. and GarcíaRodeja, E., Eds., Soils of Volcanic Regions in Europe, Springer-Verlag, Berlin, Heidelberg, 51-67. http://dx.doi.org/10.1007/978-3-540-48711-1_7

[17] Rispoli, P., Di Maio, G. and Esposito, D. (2008) Explorative Excavations at Villa dei Misteri in Pompeii (in Italian). In: Guzzo, P.G. and Guidobaldi, M.P., Eds., New Archaeological Research in the Vesuvian Area (Excavations 2003-2006) (in Italian), International Congress, Rome, 542.

[18] Vogel, S. and Märker, M. (2012) Comparison of Pre-AD 79 Roman Paleosols in Two Contrasting Paleo-Topographical Situations around Pompeii (Italy). Geografia Fisica e Dinamica Quaternaria, 35, 199-209.

[19] Brinson, M.M. (1993) A Hydrogeomorphic Classification for Wetlands. Wetlands Research Program, Technical Report WRP-DE-4, 79.

[20] Grossmann, J. and Moss, R. (1994) Variability of Water Quality in a Spruce Stand. Journal of Plant Nutrition and Soil Science, 157, 47-51.

[21] de Vries, W. and Leeters, E.E.J.M. (1994) Effects of Acid Deposition on 150 Forest Stands in the Netherlands. Chemical Composition of the Humus Layer, Mineral Soil and Soil Solution. DLO Winand Staring Centre for Integrated Land, Soil and Water Research. Rep. 69.1, Wageningen, 84 p.

[22] Manderscheid, B. and Matzner, E. (1995) Spatial and Temporal Variation of Soil Solution Chemistry and Ion Fluxes through the Soil in a Mature Norway Spruce (Picea abies (L.) Karst.) Stand. Biogeochemistry, 30, 99-114. http://dx.doi.org/10.1007/BF00002726

[23] Grossmann, J. and Udluft, P. (1991) The Extraction of Soil Water by the Suction-Cup Method: A Review. Journal of Soil Science, 42, 83-93. http://dx.doi.org/10.1111/j.1365-2389.1991.tb00093.x

[24] Scheffer, F. and Schachtschabel, P. (2010) Textbook of Soil Science (in German). Spektrum Akademischer Verlag GmbH, Heidelberg, Berlin.

[25] Grossmann, J. (1988) Physical and Chemical Processes during Sampling of Seapage Water Using Suction Cups (in German). Ph.D. Dissertation, Institute of Hydrochemistry, Technische Universität München, Munich, 147 p.

[26] Litaor, M.I. (1988) Review of Soil Solution Samplers. Water Resource Research, 24, 727-733. http://dx.doi.org/10.1029/WR024i005p00727

[27] DVWK (1990) Soil Water Sampling Using the Suction Cup Method (in German). Bd. Merkblatt 217, Berlin.

[28] Haberhauer, G. (1997) Adsorption Behaviours of Suction Cup Materials (in German). Proceedings of the 7th Lysimeter Conference, 7-9 April 1997, BAL Gumpenstein, 27-31. 
[29] Spangenberg, A., Cecchini, G. and Lamersdorf, N. (1997) Analysing the Performance of a Micro Soil Solution Sampling Device in a Laboratory Examination and a Field Experiment. Plant and Soil, 196, 59-70. http://dx.doi.org/10.1023/A:1004213006295

[30] Tischner, T., Nutzmann, G. and Pothig, R. (1998) Determination of Soil Water Phosphorus with a New Nylon Suction Cup. Bulletin of Freshwater Ecology and Inland Fisheries, 61, 325-332.

[31] Hendershot, W.H. and Courchesne, F. (1991) Comparison of Soil Solution Chemistry in Zero Tension and Ceramiccup Tension Lysimeters. Journal of Soil Science, 42, 577-583. http://dx.doi.org/10.1111/j.1365-2389.1991.tb00104.x

[32] Fillion, N., Probst, A. and Probst, J.L. (1999) Dissolved Organic Matter Contribution to Rainwater, through fall and Soil Solution Chemistry. Analusis, 27, 409-413. http://dx.doi.org/10.1051/analusis:1999270409

[33] Derome, J. (2002) Submanual on Soil Solution Collection and Analysis. ICP Forest Manual Part III, Expert Panel on Soil, 111-161.

[34] Roman, R., Caballero, R. and Bustos, A. (2002) Variability of Soil Solution Ions in Fallowland Fields in Central Spain. Edafologia, 9, 161-172.

[35] Strahm, B.D., Harrison, R.B., Terry, T.A., Flaming, B.L., Licata, C.W. and Petersen, K.S. (2005) Soil Solution Nitrogen Concentrations and Leaching Rates as Influenced by Organic Matter Retention on a Highly Productive Douglas-Fir Site. Forest Ecology and Management, 218, 74-88. http://dx.doi.org/10.1016/j.foreco.2005.07.013

[36] Delta-T Devices Ltd. (2006) User Manual for the SM200 Soil Moisture Sensor. SM200-UM-1.1, 36.

[37] Arthur, M.A. and Fahey, T.J. (1993) Controls on Soil Solution Chemistry in a Subalpine Forest in North-Central Colorado. Soil Science Society of America Journal, 57, 1122-1130. http://dx.doi.org/10.2136/sssaj1993.03615995005700040040x

[38] DIN ISO 10390 (2005) Soil Quality-Determination of pH. Beuth-Verlag, Berlin.

[39] DIN EN 13137 (2001) Characterization of Waste-Determination of Total Organic Carbon (TOC) in Waste, Sludges and Sediments. Beuth-Verlag, Berlin.

[40] DIN ISO 11261 (1997) Soil Quality-Determination of Total Nitrogen-Modified Kjeldahl Method. Beuth-Verlag, Berlin.

[41] Sadori, L. and Narcisi, B. (2001) The Postglacial Record of Environmental History from Lago di Pergusa, Sicily. The Holocene, 11, 655-670. http://dx.doi.org/10.1191/09596830195681

[42] Buccheri, G., Capretto, G., Di Donato, V., Esposito, P., Ferruzza, G., Pecatore, T., Ermolli, E.R., Senatore, M.R., Sprovieri, M., Bertoldo, M., Carella, D. and Madonia, G. (2002) A High Resolution Record of the Last Deglaciation in the Southern Tyrrhenian Sea: Environmental and Climatic Evolution. Marine Geology, 186, 447-470. http://dx.doi.org/10.1016/S0025-3227(02)00270-0

[43] Dohrmann, R. and Kaufhold, S. (2009) Three New, Quick CEC Methods for Determining the Amounts of Exchangeable Calcium Cations in Calcareous Clays. Clay Minerals Society, 57, 338-352. http://dx.doi.org/10.1346/CCMN.2009.0570306

[44] Mengel, K. and Kirkby, E.A. (2001) Principles of Plant Nutrition. Kluwer Academic Publishers, Dordrecht, 849 p. http://dx.doi.org/10.1007/978-94-010-1009-2

[45] Cinque, A., Robustelli, G. and Russo, M. (2000) The Consequences of Pyroclastic Fallout on the Dynamics of Mountain Catchments: Geomorphic Events in the Rivo d'Arco Basin (Sorrento Peninsula, Italy) after the Plinian Eruption of Vesuvius in 79 AD. Geografia Fisica e Dinamica Quaternaria, 23, 117-129.

[46] Cinque, A. and Robustelli, G. (2009) Alluvial and Coastal Hazards Caused by Long-Range Effects of Plinian Eruptions: the Case of the Lattari Mts. after the AD 79 Eruption of Vesuvius. Geological Society, London, Special Publications, 322, 155-171. http://dx.doi.org/10.1144/SP322.7

[47] Schneider, R. (1985) Palynological Analysis in the Aspromonte of Calabria (Southern Italy) (in French). Ligurian Notebooks of Prehistory and Protohistory, 2, 279-288.

[48] Ermolli, E.R. and di Pasquale, G. (2002) Vegetation Dynamics of South-Western Italy in the Last 28 kyr Inferred from Pollen Analysis of the Tyrrhenian Sea Core. Vegetation History and Archaeobotany, 11, 211-219. http://dx.doi.org/10.1007/s003340200024

[49] Shoji, S. and Takahashi, T. (2002) Environmental and Agricultural Significance of Volcanic Ash Soils. Global Journal of Environmental Research, 6, 113-135.

[50] Sahin, U., Ors, S., Ercisli, S., Anapali, O. and Esitken, A. (2005) Effect of Pumice Amendment on Physical Soil Properties and Strawberry Field Growth. Journal of Central European Agriculture, 6, 361-366.

[51] Fiorillo, F. and Wilson, R.C. (2004) Rainfall Induced Debris Flows in Pyroclastic Deposits, Campania (Southern Italy). Engineering Geology, 75, 263-289. http://dx.doi.org/10.1016/j.enggeo.2004.06.014

[52] Javaux, M. and Vanclooster, M. (2004) In Situ Long-Term Chloride Transport through a Layered, Nonsaturated Sub- 
soil. 2. Effect of Layering on Solute Transport Processes. Vadose Zone Journal, 3, 1331-1339. http://dx.doi.org/10.2136/vzj2004.1331

[53] Vogel, S. and Märker, M. (2011) Characterization of the Pre-AD 79 Roman Paleosol South of Pompeii (Italy): Correlation between Soil Parameter Values and Paleo-Topography. Geoderma, 160, 548-558. http://dx.doi.org/10.1016/j.geoderma.2010.11.003

[54] Schoeneberger, P.J., Wysocki, D.A., Benham, E.C. and Broderson, W.D. (2002) Field Book for Describing and Sampling Soils. Version 2.0. Natural Resources Conservation Service, National Soil Survey Center, Lincoln, 228.

[55] Adamo, N., Imperatrice, M.L., Mainolfi, P., Onorati, G. and Scala, F. (2007) Water-The Monitoring in Campania 20022006 (in Italian). ARPAC, Napoli, 257.

[56] Kennedy, V.C., Zellweger, G.W. and Jones, B.P. (1974) Filter Pore-Size Effects on the Analysis of Al, Fe, Mn and Ti in Water. Water Resource Research, 10, 785-790. http://dx.doi.org/10.1029/WR010i004p00785

[57] Laxen, D.P.H. and Chandler, I.M. (1982) Comparison of Filtration Techniques for Size Distribution in Freshwater. Analytical Chemistry, 54, 1350-1355. http://dx.doi.org/10.1021/ac00245a023

[58] Welp, G., Herms, U. and Brümmer, G. (1983) Influence of Soil Reaction, Redox Conditions and Organic Matter on Phosphate Concentrations of the Soil Solution (in German). Journal of Plant Nutrition and Soil Science, 146, 38-52.

[59] Madeira, M., Auxtero, E., Monteiro, F., García-Rodeja, E. and Nóvoa-Munoz, J.C. (2007) Exchange Complex Properties of Soils from a Range of European Volcanic Areas. In: Arnalf, Ó., Bartoli, F., Buurman, P., Óskarson, H., Stoops, G. and García-Rodeja, E., Eds., Soils of Volcanic Regions in Europe, Springer-Verlag, Berlin, Heidelberg, 369-385. http://dx.doi.org/10.1007/978-3-540-48711-1_27

[60] Nanzyo, M., Dahlgren, R. and Shoji, S. (1993) Chemical Characteristics of Volcanic Ash Soils. In: Shoji, S., Nanzyo, M. and Dahlgren, R., Eds., Volcanic Ash Soils_-Genesis, Properties and Utilization, Developments in Soil Science, Elsevier, Amsterdam, 145-188. http://dx.doi.org/10.1016/S0166-2481(08)70267-8

[61] De Pascale, S. and Barbieri, G. (1997) Effect of Soil Salinity and Top Removeal on Growth and Yield of Broad Bean as Green Vegetable. Scientia Horticulturae, 71, 147-165. http://dx.doi.org/10.1016/S0304-4238(97)00104-0

[62] Wagner, H.-G. (1967) The Cultural Landscape of Vesuvius. A Structural Analysis of Agriculture and Geography Considering Recent Transformations (in German). Annals of the Geographic Society of Hannover, 243.

[63] Andronico, D. and Cioni, R. (2002) Contrasting Styles of Mount Vesuvius Activity in the Period between the Avellino and Pompeii Plinian Eruptions and Some Implications for Assessment of Future Hazards. Bulletin of Volcanology, 64, 372-391. http://dx.doi.org/10.1007/s00445-002-0215-4

[64] Rolandi, G., Petrosino, P. and McGeehin, J. (1998) The Interplinian Activity at Somma-Vesuvius in the Last 3500 Years. Jouranl of Volcanology and Geothermal Research, 82, 19-52. http://dx.doi.org/10.1016/S0377-0273(97)00056-5

[65] Stothers, R.B. and Rampino, M.R. (1983) Volcanic Eruptions in the Mediterranean before AD 630 from Written and Archaeological Sources. Journal of Geophysical Research, 88, 6357-6371. http://dx.doi.org/10.1029/JB088iB08p06357

[66] Holliday, V.T. (2004) Soils in Archaeological Research. Oxford University Press, Oxford, 448.

[67] Dimbleby, G.W. (1984) Anthropogenic Changes from Neolithic through Medieval Times. New Phytologist, 98, 57-72. http://dx.doi.org/10.1111/j.1469-8137.1984.tb06098.x

[68] Thomas, R.M.E. and Sparks, R.S.J. (1992) Cooling of Tephra during Fallout from Eruption Columns. Bulletin of Volcanology, 54, 542-553. http://dx.doi.org/10.1007/BF00569939 
Scientific Research Publishing (SCIRP) is one of the largest Open Access journal publishers. It is currently publishing more than 200 open access, online, peer-reviewed journals covering a wide range of academic disciplines. SCIRP serves the worldwide academic communities and contributes to the progress and application of science with its publication.

Other selected journals from SCIRP are listed as below. Submit your manuscript to us via either submit@scirp.org or Online Submission Portal.
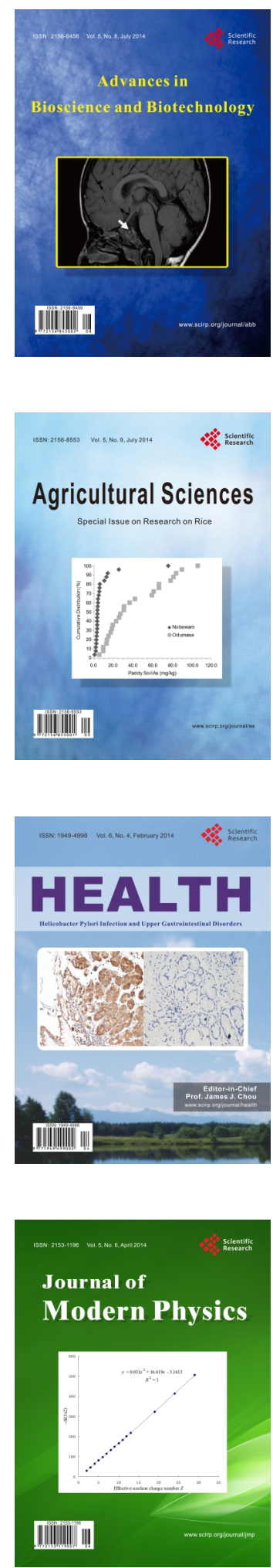
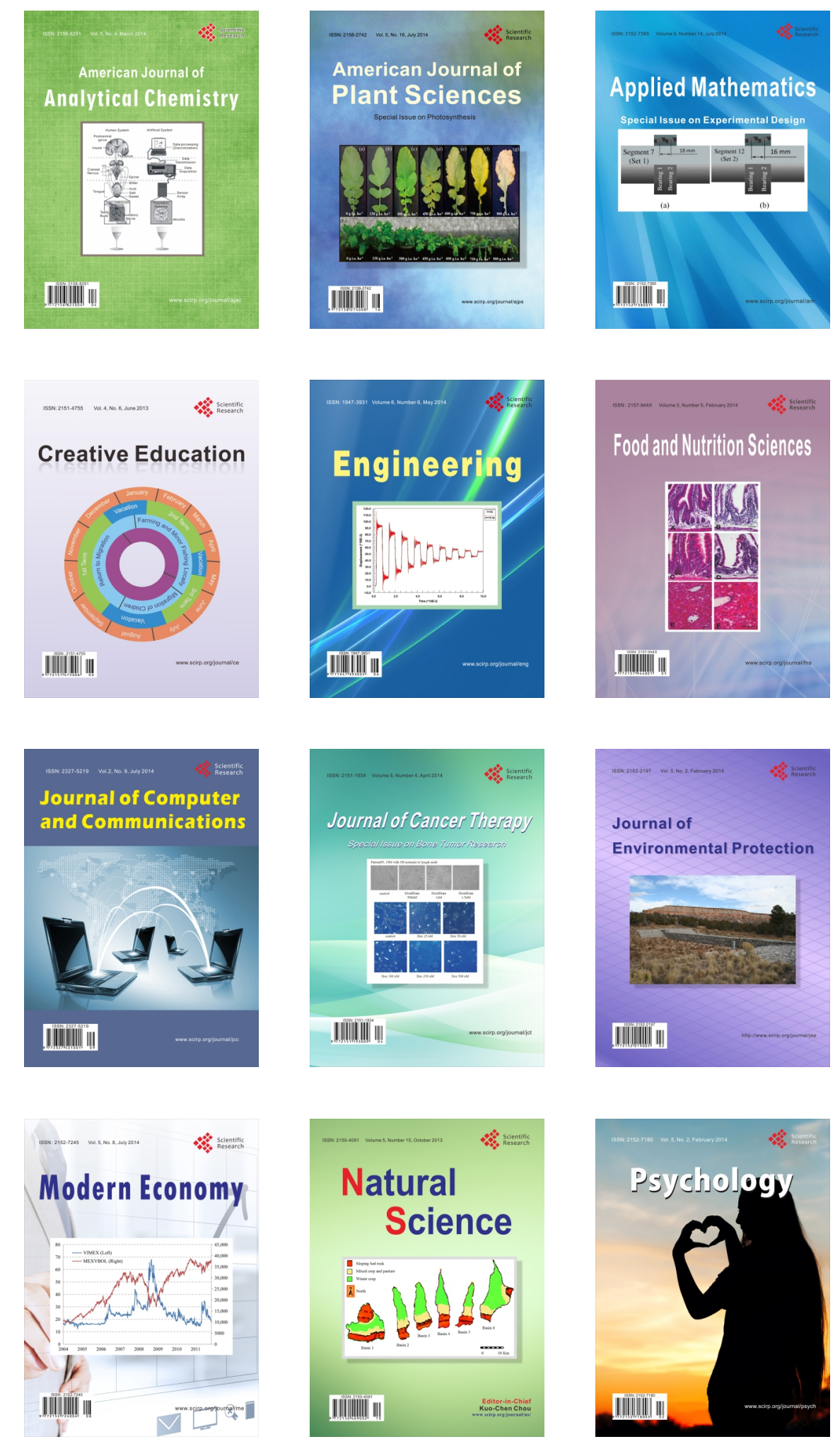